\title{
A tripartite inquiry into volatility-efficiency- integration nexus - case of emerging markets
}

Article

Accepted Version

Creative Commons: Attribution-Noncommercial-No Derivative Works 4.0

Rizvi, S. A.R., Arshad, S. and Alam, N. (2018) A tripartite inquiry into volatility-efficiency-integration nexus - case of emerging markets. Emerging Markets Review, 34. pp. 143161. ISSN 1566-0141 doi:

https://doi.org/10.1016/j.ememar.2017.11.005 Available at https://centaur.reading.ac.uk/81607/

It is advisable to refer to the publisher's version if you intend to cite from the work. See Guidance on citing.

To link to this article DOI: http://dx.doi.org/10.1016/j.ememar.2017.11.005

Publisher: Elsevier

All outputs in CentAUR are protected by Intellectual Property Rights law, including copyright law. Copyright and IPR is retained by the creators or other copyright holders. Terms and conditions for use of this material are defined in the End User Agreement.

www.reading.ac.uk/centaur

\section{CentAUR}


Central Archive at the University of Reading

Reading's research outputs online 


\section{Accepted Manuscript}

A tripartite inquiry into volatility-efficiency-integration nexus case of emerging markets

Syed Aun R. Rizvi, Shaista Arshad, Nafis Alam

PII: S1566-0141(17)30211-X

DOI: doi:10.1016/j.ememar.2017.11.005

Reference: EMEMAR 535

To appear in:

Received date: 26 May 2017

Revised date:

Accepted date: 19 November 2017

Please cite this article as: Syed Aun R. Rizvi, Shaista Arshad, Nafis Alam, A tripartite inquiry into volatility-efficiency-integration nexus - case of emerging markets. The address for the corresponding author was captured as affiliation for all authors. Please check if appropriate. Ememar(2017), doi:10.1016/j.ememar.2017.11.005

This is a PDF file of an unedited manuscript that has been accepted for publication. As a service to our customers we are providing this early version of the manuscript. The manuscript will undergo copyediting, typesetting, and review of the resulting proof before it is published in its final form. Please note that during the production process errors may be discovered which could affect the content, and all legal disclaimers that apply to the journal pertain. 


\section{A Tripartite Inquiry into Volatility-Efficiency-Integration Nexus - Case of Emerging Markets}

Dr. Syed Aun R. Rizvi (Corresponding Author)

Suleman Dawood School of Business,

Lahore University of Management Sciences,

Lahore, Pakistan.

E-mail: aun@rizvis.net

\section{Shaista Arshad}

Nottingham University Business School

The University of Nottingham Malaysia Campus

Email: shaistaarshad@gmail.com

Dr. Nafis Alam

Henley Business School

The University of Reading Malaysia

E-mail: n.alam@henley.edu.my 


\title{
A Tripartite Inquiry into Volatility-Efficiency-Integration Nexus - Case of Emerging Markets ${ }^{1}$
}

\begin{abstract}
The objective of this paper is to analyse the time-varying changes of the three parameters, volatility, efficiency and integration on stock markets across emerging markets. We do this using a four-step process with focus on Multifractal Detrended Fluctuation Analysis to measure its efficiency. Our analysis show that lower volatility was found in short-term for countries that experienced fast paced economic growth. This increase in volatility is supported by a decrease in efficiency for the short-term, while market integration rose during periods of crises, which represent higher volatility. Hence, a tripartite relationship between our parameters is observed.
\end{abstract}

JEL classifications: C22; E44; G1

Keywords: Emerging Markets; Decomposed Returns; Stock market efficiency; Stock Market Integration; Multifractal

\footnotetext{
${ }^{1}$ We would like to thank Professor Jonathan Batten and Professor Paresh Narayan and the participants at IFABS 2016 Conference for their kind feedback and comments in improving this study.
} 


\section{Introduction}

Financial literature is rife with discussion on the linkages between stock markets and economic growth. However, most document a singular or dual approach in analysing the linkages. Karim and Ning (2013), Wai and Cheung (2000), Kang and Yoon (2011) are amongst those who analysed the stock market's volatility and integration. They found presences of stronger integration during periods of intensified volatility. Hooy and Lim (2013), Rockinger and Urga (2001) and Schotman and Zalewska (2006) are amongst the few to straddle efficiency and integration together. This group associated increased integration with higher risk attributes.

When discussing the links between stock market and economic growth, an important troika to analyse is the efficiency, integration and volatility of stock markets. An efficient market ensures that all parties are privy to the same information and risks, allowing optimal resource allocation, which in turn increases economic growth (Griffin et. al ,2009; Laopodis, 2004.) The extent of efficiency in a market is often characterized by its volatility, whereby the higher the volatility, the more unpredictable it would seem to market players and hence reducing its efficiency (Greenspan, 2000; Larrain, 2004; Piyapas, 2007 and Mills, 2000). Furthermore, national and international events often pave way for high volatility in stock markets, indicating that integration plays a significant role in the volatility of the stock markets (Kim et al. 2006; Dewandaru et. al. 2014a, b and Rizvi et al. 2015). This is indicative of the interconnectedness of the volatility, efficiency and integration of a stock market, making them significant in analysing stock markets and economic growth.

The objective of this paper is to analyse the time-varying changes of the three parameters (i.e. volatility, efficiency and integration) in stock markets across emerging markets. A time-varying analysis is undertaken as singular measures of any of the 3 variables are insufficient in explaining the deviations of a stock market and as such we would be unable to understand properly its relationship with economic growth. Time-varying analyses often utilize business cycles as an indicator of different economic situations. Siliverstovs and Duong, 2006; Fama, 1990; Binswanger, 2000; Antonios, 2010 are amongst the many who have worked with business cycles in analysing the relationship between stock markets and economic growth.

We define the economic state as a general state of global economy in an economic growth or general slowdown/recession. The classifications being followed are from Rizvi et. 
al. (2014), Arshad et. al. (2014) and Alam et al. (2016). They are mainly the 3 major economic crises that have affect stock markets significantly over the time period of this study.

In order to achieve the above-mentioned objective, a four-step process is employed. Firstly, we employ wavelet decomposition to decompose the daily return series into timescales, to distinguish between short term and long term. Secondly, EGARCH analysis is used to calculate the volatility of the return series in different economic cycles. Thirdly, we use MGARCH analysis to determine integration of the emerging markets with the world market. Fourthly, to explore the efficiency levels of the markets in different economic times, we employ Multifractal Detrended Fluctuation Analysis (MFDFA) to measure its efficiency.

Our approaches lead to three general conclusions. Firstly, when analysing the volatility of our sample countries, lower volatility was found in short-term for countries that experienced fast paced economic growth, in other words, post-liberalization (see Arshad and Rizvi, 2015 for similar results). Secondly, this increase in volatility is supported by a decrease in efficiency for the short-term, as stocks markets which tend to become more liquid will tend to be more volatile in shorter horizon. Thirdly, market integration rose during periods of crises, which represent higher volatility (see Dewandaru, et al., 2014b; Arshad, et. al. 2014 for similar results).

Overall, these results contribute to existing literature in several ways. Firstly, this study contributes to the growing literature on the stock market efficiency and volatility in the developing markets (Rizvi et al. 2014, Arshad and Rizvi 2015, Rizvi and Arshad 2016, dewandaru et al. 2015 etc.). These studies have delved into the deliberations that a stock market's volatility, efficiency and integration are greatly interconnect and must be used together when making policies or investment planning. Secondly, this paper contributes significantly to existing literature, as it is to the best of our knowledge that this is the most comprehensive study covering 21 emerging stock markets and only a few studies have undertaken to analyse the troika of volatility, efficiency and integration (Arshad and Rizvi, 2015 and Arshad, et. al. 2014). Thirdly this paper is unique as per our knowledge as it attempts to explore whether there is a causal relationship between the three parameters of the stock markets in emerging economies. Fourthly the paper contributes to the growing literature on the non-linear decomposed studies of stock markets recently which hypothesize that the behaviour of the stock markets is different in terms of their short term and long term components (Dewandaru et. al. 2015, Masih et al. 2014, Alam et al. 2016 etc.). 
In order to validate our results, the empirical analysis is subjected to three robustness checks. First, all three analyses incorporate splitting the data to different economic states time periods, where we observe similar patterns hold. Second, the stock market data is further fragmented into short-term and long-term components using wavelet decomposition. This allows for an in-depth analysis of how the stock market is affected based on short-term noise and long-term fundamentals. Third, the nexus of volatility, efficiency and integration is analysed to see whether the relationship holds. Using pooled OLS regression, the relationships between efficiency and volatility and integration and volatility are analysed. The accompanying results coincide with our previous analysis that in the shorter horizon, higher volatility in an emerging market would result in a lower integration and efficiency (lower the efficiency score, the better) and vice versa.

The remainder of the paper is structured as follows. Following the introduction, Section 2 explores the data and sample countries, for their basic measures. This is followed by a brief discussion of the methodology in Section 3. Section 4, explores the empirical results and the concluding remarks as well as some policy implications are presented in Section 5.

\section{Data and Sample Countries}

Our data set comprises of 21 stocks markets from the emerging economies. The classification of emerging economies has been taken from the Morgan Stanley Composite Indices (MSCI) classification comprising of the measurement of economic development, size and liquidity as well as market accessibility.

The Morgan Stanley Composite Index criteria, narrows down the emerging stock markets to 23 markets across the globe. In our sample we had to restrict to 21 , owing to unavailability of data for United Arab Emirates and Qatar, which is only available from 2005 onwards. Our sample period runs from 1 January 2001 till 31 December 2014 for the benchmark indices. In this case, we have 4750 observations for each emerging market, covering a span of 13 years. Daily returns are calculated using the equation $r_{t}=\ln \left(P_{t}\right)-\ln \left(P_{t-}\right.$ $\left.{ }_{1}\right)$. Here, $r_{t}$ and $P_{t}$ denote daily return and price at the business day $t$ respectively.

The sample countries are presented in Table 1. The countries have been classified in three regional groups namely Americas, Europe and Africa and Asia. The regional classification is based on the MSCI classification for grouped market behaviour. 


\begin{tabular}{|c|c|c|}
\hline AMERICAS & EUROPE AND AFRICA & ASIA \\
\hline Brazil & Czech & China \\
Chile & Egypt & India \\
Colombia & Greece & Indonesia \\
Mexico & Hungary & Malaysia \\
Peru & Poland & Philippines \\
& Russia & South Korea \\
& S. Africa & Taiwan \\
& Turkey & Thailand \\
\hline \multicolumn{2}{|c|}{ Note: This table provides a list of emerging markets selected. 5 } \\
countries are taken from the Americas regions, 8 countries from \\
Europe and Africa and 8 countries from Asia \\
\hline
\end{tabular}

Table 1a: List of Sample Countries

For a robust understanding of the behaviour of the emerging markets across the troika of stock market indicators under study, we have divided our data into three time periods, to factor in different phases the world markets have gone through in the sample period. 20012002 , is the initial time period, when markets in developed countries went through turmoil in the aftermath of the corporate scandals like Enron and WorldCom, in addition to the September 2001, World Trade Centre bombings. Post 2002, the markets experienced a normal phase of steady economic growth up till 2006, where the global economies picked up and no major stock market or economic or financial market crashes were witnessed. This period is classified as the normal boom period and lasts from 2003 to 2006. Post normal period, till 2014, has been classified as the crisis period, which originated from the financial sector in US and translated into a global economic slowdown.

Table 1b, presents the key economic measures of the sample countries. The economic measures, for each sample period, are appended in Appendix I. The overall economic measures, present diverging figures, for different regions. While for Americas and Europe and African economies grew at an average of 3-\% over the sample 14 year period, the average for Asian region is higher which can be attributed to the fast paced growth of Chinese and Indian economy. The country which stands out is the Greek economy which has an overall negative average, which is primarily because of the Greek crisis in recent years, and is evident in our further classified regimes. During 2007-2014, on an average the Greek economy has shrunk by nearly $3 \%$ pulling down the complete sample period average. We have also classified our sample countries according to the exchange rate regimes they follow, as the literature suggest a stable currency to be attractive for development of the stock markets in emerging countries. 
The development stage of Stock markets is represented in Table 1b, through the size of the stock market and the liquidity of these markets. Generally the markets in emerging economies are mid-sized with the exception with the South African and Malaysian market. Taking a cursory glance at the sub divided time periods, there is a trend of increasing market size and improving liquidity situation, primarily for the BRIC (Brazil, Russia, China and India) and the East Asian economies over the last one and a half decade.

\begin{tabular}{|c|c|c|c|c|}
\hline \multicolumn{5}{|c|}{ FULL TIME PERIOD } \\
\hline & GDP GROWTH & MARKET SIZE/GDP & LIQUIDITY & CURRENCY \\
\hline AMERICAS & $3.9 \%$ & $56.6 \%$ & $22.8 \%$ & \\
\hline Brazil & $3.3 \%$ & $54.1 \%$ & $52.8 \%$ & Floating \\
\hline Chile & $4.2 \%$ & $107.7 \%$ & $15.9 \%$ & Floating \\
\hline Colombia & $4.3 \%$ & $41.7 \%$ & $11.1 \%$ & Floating \\
\hline Mexico & $2.1 \%$ & $30.8 \%$ & $27.4 \%$ & Floating \\
\hline Peru & $5.7 \%$ & $48.8 \%$ & $6.6 \%$ & Floating \\
\hline EUROPE AND AFRICA & $3.0 \%$ & $54.4 \%$ & $66.1 \%$ & \\
\hline Czech Republic & $2.5 \%$ & $22.6 \%$ & $54.3 \%$ & Floating \\
\hline Egypt, Arab Rep. & $4.2 \%$ & $47.5 \%$ & $36.3 \%$ & Floating \\
\hline Greece & $-0.02 \%$ & $42.0 \%$ & $48.1 \%$ & Currency Union \\
\hline Hungary & $1.7 \%$ & $22.1 \%$ & $76.1 \%$ & Currency Union \\
\hline Poland & $3.6 \%$ & $29.4 \%$ & $40.5 \%$ & Floating \\
\hline Russian Federation & $4.5 \%$ & $56.6 \%$ & $69.6 \%$ & Floating \\
\hline South Africa & $3.3 \%$ & $184.5 \%$ & $51.3 \%$ & Floating \\
\hline Turkey & $4.2 \%$ & $30.5 \%$ & $152.3 \%$ & Floating \\
\hline ASIA & $5.8 \%$ & $72.6 \%$ & $91.3 \%$ & \\
\hline China & $10.0 \%$ & $62.8 \%$ & $134.6 \%$ & Floating* \\
\hline India & $7.2 \%$ & $66.6 \%$ & $102.4 \%$ & Floating \\
\hline Indonesia & $5.5 \%$ & $33.4 \%$ & $48.3 \%$ & Floating \\
\hline Malaysia & $4.8 \%$ & $139.7 \%$ & $31.0 \%$ & Floating* \\
\hline Philippines & $5.0 \%$ & $60.5 \%$ & $18.6 \%$ & Floating \\
\hline Korea, Rep. & $4.1 \%$ & $74.4 \%$ & $213.4 \%$ & Floating* \\
\hline Thailand & $4.1 \%$ & $70.8 \%$ & $90.9 \%$ & Floating \\
\hline \multicolumn{5}{|c|}{$\begin{array}{l}\text { Notes: This table details the key economic statistics for sample countries. The first indicator is the GDP growth. } \\
\text { The second indicator is Market Size/GDP. This represents the Average Market Capitalization as a ratio of the } \\
\text { Real GDP during the period. The third indicator is Liquidity which represents the Total Turnover in the stock } \\
\text { market. It is calculated as Total Value of Shares traded as a ratio of market capitalization. The data for columns } \\
\text { 2-4 have been obtained from the WorldBank Database. The last column shows the Exchange Rate Regime that } \\
\text { has been acquired from Official IMF classifications of Exchange Rate Agreements. }\end{array}$} \\
\hline
\end{tabular}

Table 1b. Key Economic Statistics

\section{Methodology}

This study follows a four-step process in an attempt to explore the nexus for emerging markets. At stage 1, we employ Wavelet decomposition to decompose the daily return series into timescales, to distinguish between short term and long term, followed by an EGARCH 
analysis to calculate the volatility of the return series in different economic cycles. Next, we use MGARCH analysis to determine integration of the emerging markets with the world market. Lastly, to explore the efficiency levels of the markets in different economic times, we employ Multifractal Detrended Fluctuation Analysis to measure the efficiency. The following section presents a brief discussion on the four methodologies.

\subsection{Wavelet}

Taking the return series for every stock index, we use wavelet analysis to be able to separate out each return series into its constituent multiresolution (multihorizon) components. To do that we apply Maximum Overlap discrete wavelet transformation (MODWT) on daily return series by sampling the return series at evenly-spaced points in time. We transform the return series from time domain into scale (interval) domain in order to understand the frequency at which the activity in the time series occurs. In our study, we sample the daily return series at different scale crystals (j) as follows: d1 (2-4 days), d2 (4-8 days) days, d3 (8-16 days), d4 (16-32 days), d5 (32-64 days), and s5 (>64 days). Application of wavelet has recently surged in financial literature as it allows capturing the non-linearity property of the financial time series data. Caetano and Yoneyama (2012), Arshad et al. (2014), Dewandaru et al. (2014a), Arshad and Rizvi (2015), Aloui et al. (2015), have all explored the application of wavelet in answering questions related to stock market data. Most of these studies find wavelet decomposition as a more reliable method since it preserves the original properties of the stock market time series.

We use non-decimated orthogonal Maximum Overlap Discrete Wavelet Transform (MODWT) with symmlet 8 as a wavelet function to obtain a multi-scale decomposition of the return series. The Maximum Overlap Discrete Wavelet Transform (MODWT) will be used with the advantage on the flexibility of the length of data (not requiring the integral power of two) as well as time invariant property. The wavelet family symmlet 8 is chosen to get the least asymmetry property which is more appropriate for financial series. The transformed return series $\mathrm{r}(\mathrm{t})$ is represented as a linear combination of wavelet functions as follows:

$r(t) \approx \sum_{k} s_{j, k} \boldsymbol{\phi}_{j, k}(t)+\sum_{k} d_{j, k} \boldsymbol{\Psi}_{j, k}(t)+\sum_{k} d_{j-1, k} \boldsymbol{\Psi}_{j-1, k}(t)+\cdots \sum_{k} d_{1, k} \boldsymbol{\Psi}_{1, k}(t)$

where:

$\mathrm{j}$ is the number of scale crystals (intervals or frequencies)

$\mathrm{k}$ is the number of coefficients in the specified component

$\phi_{j, k(t)}$ and $\psi_{j, k(t)}$ are the father and mother orthogonal wavelet pair that are given respectively by

$$
\phi_{j, k}(t)=2^{-j / 2} \phi\left(\frac{t-2^{j} k}{2^{j}}\right) \text { for } j=1 \text { to } j
$$




$$
\psi_{j, k}(t)=2^{-j / 2} \psi\left(\frac{t-2^{j} k}{2^{j}}\right) \text { for } j=j \text { to } 11
$$

We use the summation of the decomposed scale d1 (2-4 days) and d2 (4-8 days) to represent the short term investor horizon, while the d5 (32-64 days), and s5 (>64 days) represent the long term investor horizon for our study.

\subsection{Exponential GARCH Volatility}

GARCH models have been extensively used in studying the volatility of stock markets in finance literature for both simple volatility and decomposed. Hammoudeh and Choi (2007) used univariate GARCH model within two volatility regimes of Markov switch to examine the volatility behavior for the transitory and permanent components of each GCC stock market. In a latter study Yu and Hassan (2008) employed the EGARCH models for the Middle Eastern and North African countries. This study was extended by Hammoudeh et al. (2009) used a multivariate VAR-GARCH to examine the dynamic volatility and volatility transmission for the service, financial and industrial sectors of Kuwait, Qatar, Saudi Arabia and the UAE.

In our study, looking at the ordinary GARCH model, we can see that the conditional variance is allowed to be dependent on its past, however this standard model possess some limitations as it cannot include the leveraging effects, nor can it allow for a direct response between conditional variance and conditional mean. Hence, in this study we concentrate on the asymmetric GARCH model developed by Nelson (1991), the EGARCH model which is better suited for volatilities. The EGARCH model presides over other models with its ability to allow for a more stable optimization of routines, and no parameter constraints.

$$
\ln \sigma_{j, t}^{2}=\omega_{t}+\beta_{j} \ln \left(\sigma_{j, t-1)}^{2}+\gamma \frac{\varepsilon_{t-1}}{\sqrt{\sigma_{t-1}^{2}}}+\alpha\left[\frac{\left|\varepsilon_{t-1}\right|}{\sqrt{\sigma_{t-1}^{2}}}-\sqrt{\frac{2}{\pi}}\right]\right.
$$

Where $\sigma_{j, t}^{2}$ denotes the conditional variance since it is a one-period ahead estimate for the variance calculated on any past relevant information. $\omega_{t}$ symbolizes a conditional density function. The $\alpha$ consideration represents a symmetric effect of the model, i.e. the GARCH effect. $\beta$ calculates the perseverance in conditional volatility irrespective of market movements. Furthermore, the parameter $\gamma$ measures the leveraging effect. 


\subsection{Multivariate GARCH Correlation}

Moving on from the volatility aspect of our analysis, in order to determine the correlation as the integration measure for the decomposed series, we use Multivariate GARCH. MGARCH allows us to calculate the correlations, which can be used as a proxy for integration of the Turkish stock market with the regional benchmarks. Bauwens et. al. (2006) have reviewed MGARCH and its various applicability and have found it to be suitable for testing correlations and cointegration amongst countries. A brief technical note on the methodology is as follows.

Let $\mathrm{rt}$ be an $\mathrm{m} \mathrm{x} 1$ vector of asset returns at close day $\mathrm{t}$ assumed to have a conditional multivariate $\mathrm{t}$ distribution with means, $\mu \mathrm{t}-1$, and the non-singular variance-covariance matrix $\Sigma \mathrm{t}-1$, and vt-1 $>2$ degrees of freedom. Here we are not concerned with how mean returns are predicted and take $\mu \mathrm{t}-1$ as given. For specification of $\Sigma \mathrm{t}-1$ we follow Bollerslev (1990) and Engle (2002) consider the decomposition.

$$
\Sigma_{t-1}=D_{t-1} R_{t-1} D_{t-1}
$$

where,

$$
\begin{aligned}
D_{t-1} & =\left(\begin{array}{ccccc} 
& \sigma_{1, t-1} & & \\
& & & \sigma_{2, t-1} & 0 \\
& & & 0 & \\
& & & & \sigma_{m, t-1}
\end{array}\right) \\
R_{z-1} & =\left(\begin{array}{ccccc}
1 & \rho_{12, t-1} & \rho_{13, t-1} & \ldots & \rho_{1 m, t-1} \\
\rho_{21, t-1} & 1 & \rho_{23, t-1} & \ldots & \rho_{2 m, t-1} \\
\rho_{31, t-1} & \rho_{32, t-1} & 1 & \ldots & \rho_{3 m, t-1} \\
\rho_{m 1, t-1} & \cdots & \rho_{m, m-1, t-1} & \rho_{m-1, m, t-1}
\end{array}\right)
\end{aligned}
$$

Rt-1 $=(\rho \mathrm{ij}, \mathrm{t}-1)=(\rho \mathrm{ji}, \mathrm{t}-1)$ is the symmetric $\mathrm{m} \times \mathrm{m}$ correlation matrix, and Dt-1 is the $\mathrm{m} \times \mathrm{m}$ diagonal matrix with $\sigma \mathrm{i}, \mathrm{t}-1 ; \mathrm{i}=1,2, \ldots, \mathrm{m}$ denoting the conditional volatility of the $\mathrm{i}$-th asset return. (Further discussion of methodology is available in appendix II)

This procedure has two main drawbacks. First, the Gaussianity assumption does not hold for daily returns and its use can under-estimate the portfolio risk. Second, the two-stage approach is likely to have even coefficient under Gaussianity.

\subsection{Multifractal Detrended Fluctuation Analysis}

In the attempt of understanding the efficiency of these stock markets we employ multifractal de-trended fluctuation analysis (MFDFA) on our original return series. The MFDFA is 
proficient in measuring the efficiency as it allows us to sequentially rank the individual efficiency of market. MFDFA, has recently become popular in the financial literature with rizvi et al. (2014), Dutta et al (2014), Batten et. Al. (2014), Arshad and Rizvi (2015), Dewandaru et al. (2014a), all focusing on the fractal nature of financial markets to investigate their behaviour under new light. Furthermore, it can determine the extent of the inefficiency. Additionally as compared to other efficiency measurement methods in finance mf-dfa keeps the non linear nature of financial series intact, which is more closer to reality. Borrowing from Kantelhardt et al., (2002) the procedural details of MFDFA, are summarized below:

Firstly, the analysis begins with a correlated time series (signal) $\{$ ui, $\mathrm{i}=1, \ldots, N\}$, where $N$ is the size of the series, the corresponding profile is determined by integration

$$
d f Y(k)=\sum_{i=1}^{k}\left[u_{i}-(u)\right], \quad k=1, \ldots, N,
$$

Post the creation of corresponding profile $\mathrm{Y}(\mathrm{k})$ is further divided into non overlapping windows of equal length s. In this study the window used is 4 days. The record length of $\mathrm{s}$ does not need to be a multiple of the time scale s, a short part at the end of the profile will exist in most cases. To counter this problem, the same process is repeated starting from the other end, thus resulting in 2N's windows.

To evaluate the local trend of each window $v=1, \ldots, 2 \mathrm{Ns}$ least square fit of the data is taken into account. The de-trended time series is denoted by $\mathrm{Y}_{\mathrm{S}}(\mathrm{i})$, and is calculated as the difference between the original time series and the fits,

$$
Y_{s}(i)=Y\left[\left(v-N_{s}\right) s+1\right]-p_{v}(i)
$$

For $v=1, \ldots, \mathrm{N}_{\mathrm{s}}$, and

$$
Y_{s}(i)=Y\left[N-\left(v-N_{s}\right) s+1\right]-p_{v}(i)
$$

For $v=\mathrm{Ns}+1, \ldots, 2 \mathrm{Ns}$. Here, p(i) is the fitting polynomial in the $v_{\text {th }}$ window. Since the de-trending of the time series is done by subtraction of the fits from the profile, these methods differ in their capability of eliminating trends in the data. In mth order of MFDFA, trends of order $m$ in the profile and $m-1$ in the original record are eliminated. Thus, a comparison of the results for different orders of MFDFA allows estimation of the polynomial trend in the time series. Since we use a polynomial fit of order 3, we denote the algorithm as MFDFA-3.

The variance for both of $2 \mathrm{~N}_{\mathrm{s}}$ of the de-trended time series $\mathrm{Y}_{\mathrm{s}}(\mathrm{i})$ is evaluated by averaging over all data point $\mathrm{i}$ in the $v_{\text {th }}$ window

$$
F_{s}^{2}(v)=\frac{1}{s} \sum_{i=1}^{s}\left(Y_{s}(i)\right)^{2}
$$

The qth order fluctuation function is obtained by averaging over all segments 


$$
F_{q}(s)=\left\{\frac{1}{N_{s}} \sum_{v=1}^{N_{s}}\left[F_{s}^{2}(v)\right]^{q / 2}\right\}^{1 / q}
$$

Starting from the beginning, and starting from the end.

$$
F_{q}(s)=\left\{\frac{1}{N_{S}} \sum_{v=N_{S}+1}^{2 N_{S}}\left[F_{S}^{2}(v)\right]^{q / 2}\right\}^{1 / q}
$$

The order $\mathrm{q}$ can take any real value. For $\mathrm{q}=0$ the value $\mathrm{h}(0)$ cannot be determined directly because of the diverging exponent. Instead, a logarithmic average procedure has to be employed. For $\mathrm{q}=2$, the standard DFA procedure is retrieved.

Finally, the scaling behavior of the fluctuation is determined by analyzing log-log plots of $\mathrm{Fq}(\mathrm{s})$ versus $\mathrm{s}$ for each value of $\mathrm{q}$. If the series $\mathrm{u}_{\mathrm{i}}$ are long-range correlated $\mathrm{Fq}(\mathrm{s})$ increases, for large values of s, as a power-law

$$
F_{q}(s) \sim s^{h(q)}
$$

For a stationary time series, the profile defined in Eq. (6) will be a fractional Brownian motion $(\mathrm{fBm})$. Thus, $0<\mathrm{h}(\mathrm{q}=2)<1$ for these processes, and $\mathrm{h}(\mathrm{q}=2)$ is identical with the Hurst parameter, $\mathrm{H}$. Contrary to this, if the original signal is a $\mathrm{fBm}$, the profile will be a sum of $\mathrm{fBm}$, so $\mathrm{h}(\mathrm{q}=2)>1$. In this particular scenario, the relationship between the exponent $\mathrm{h}(\mathrm{q}=2)$ and $\mathrm{H}$ is $\mathrm{H}=\mathrm{h}(\mathrm{q}=2)-1$. Thus, the exponent $\mathrm{h}(\mathrm{q})$ is usually known as the generalized Hurst exponent.

\section{Empirical results}

Literature stresses on the importance of an efficient and integrated and stable stock market in the economic growth of a country and regionally. They play a critical role in in increasing savings and investment allowing for efficacious economic development. From the perspective of international portfolio investors, the equity markets allow diversification across a variety of assets, which assists in reducing the risk of the investor in turn reducing the cost of capital, which accordingly provides a catalyst for investment and economic growth.

An inefficient market, which will cause the investors to face difficulty in choosing the optimal investment as information on corporate performance, is slow or less viable. The resulting uncertainty may induce investors either to withdraw from the market until this uncertainty is resolved or discourage them to invest funds for long term. In light of these, the following analysis delves into the nexus of the volatility, efficiency and integration levels of 
21 emerging stock markets, where we explore the dynamics and characteristic of these countries' stock markets through different phases.

\subsection{Volatility Paradigm in Emerging Markets.}

The findings of the volatility paradigm across the emerging world provide some interesting insights into the behaviour of these markets as presented in Table 2. At the initial stage, a cursory look at the volatility across the whole sample period shows evidence of a higher relative volatility in general for the Asian emerging markets.

An interesting aspect which stands out is the lower volatility in the shorter term for countries that experienced fast paced economic growth combined with relative liberalization like Chile and Colombia from Americas, in Europe and Africa, countries like Czech, Greece and Hungary, while in Asia these countries are Malaysia, Taiwan and South Korea. These finding are relatively similar to what Arshad and Rizvi (2015) found in the case of East Asian markets.

\begin{tabular}{|c|c|c|c|c|c|c|c|c|c|}
\hline & \multirow{2}{*}{\multicolumn{2}{|c|}{ 2001-2014 }} & \multirow{2}{*}{\multicolumn{2}{|c|}{$2001-2003$}} & \multirow{2}{*}{\multicolumn{2}{|c|}{ 2003-2006 }} & \multirow{2}{*}{\multicolumn{2}{|c|}{ 2007-2014 }} \\
\hline & & & & & & & & & \\
\hline \multirow[b]{2}{*}{ Americas } & & ST & LT & ST & LT & ST & LT & ST & LT \\
\hline & $\begin{array}{c}\text { Brazil } \\
\text { Chile } \\
\text { Colombia } \\
\text { Mexico } \\
\text { Peru }\end{array}$ & $\begin{array}{l}1.30 \% \\
0.79 \% \\
0.98 \% \\
1.04 \% \\
1.36 \%\end{array}$ & $\begin{array}{l}1.58 \% \\
0.96 \% \\
1.26 \% \\
1.29 \% \\
1.69 \%\end{array}$ & $\begin{array}{l}0.80 \% \\
0.69 \% \\
0.80 \% \\
0.69 \% \\
0.91 \%\end{array}$ & $\begin{array}{l}1.63 \% \\
0.80 \% \\
1.09 \% \\
1.44 \% \\
1.12 \%\end{array}$ & $\begin{array}{l}1.19 \% \\
0.66 \% \\
1.09 \% \\
0.93 \% \\
1.20 \%\end{array}$ & $\begin{array}{l}1.43 \% \\
0.80 \% \\
1.43 \% \\
1.14 \% \\
1.43 \%\end{array}$ & $\begin{array}{l}1.36 \% \\
0.89 \% \\
0.96 \% \\
1.08 \% \\
1.58 \%\end{array}$ & $\begin{array}{l}1.65 \% \\
1.10 \% \\
1.20 \% \\
1.33 \% \\
1.97 \%\end{array}$ \\
\hline \multirow{3}{*}{$\begin{array}{c}\text { Europe } \\
\text { and } \\
\text { Africa }\end{array}$} & \multirow{3}{*}{$\begin{array}{c}\text { Czech } \\
\text { Egypt } \\
\text { Greece } \\
\text { Hungary } \\
\text { Poland } \\
\text { Russia } \\
\text { S. Africa } \\
\text { Turkey }\end{array}$} & ST & LT & ST & LT & ST & LT & ST & LT \\
\hline & & $\begin{array}{l}1.16 \% \\
1.28 \% \\
1.45 \% \\
1.36 \% \\
1.22 \% \\
1.66 \% \\
1.00 \% \\
1.72 \%\end{array}$ & $\begin{array}{l}1.43 \% \\
1.67 \% \\
1.69 \% \\
1.66 \% \\
1.52 \% \\
2.10 \% \\
1.23 \% \\
2.21 \%\end{array}$ & $\begin{array}{l}1.33 \% \\
1.03 \% \\
1.22 \% \\
1.31 \% \\
1.38 \% \\
1.88 \% \\
1.07 \% \\
2.61 \%\end{array}$ & $\begin{array}{l}1.62 \% \\
1.35 \% \\
1.54 \% \\
1.59 \% \\
1.71 \% \\
2.44 \% \\
1.34 \% \\
3.34 \%\end{array}$ & $\begin{array}{l}1.06 \% \\
1.34 \% \\
0.94 \% \\
1.15 \% \\
1.09 \% \\
1.57 \% \\
0.95 \% \\
1.73 \%\end{array}$ & $\begin{array}{l}1.33 \% \\
1.79 \% \\
0.90 \% \\
1.41 \% \\
1.37 \% \\
1.95 \% \\
1.15 \% \\
2.18 \%\end{array}$ & $\begin{array}{l}1.17 \% \\
1.31 \% \\
1.80 \% \\
1.50 \% \\
1.25 \% \\
1.66 \% \\
1.02 \% \\
1.47 \%\end{array}$ & $\begin{array}{l}1.44 \% \\
1.70 \% \\
2.18 \% \\
1.82 \% \\
1.54 \% \\
2.09 \% \\
1.25 \% \\
1.91 \%\end{array}$ \\
\hline & & ST & LT & ST & LT & ST & LT & ST & LT \\
\hline
\end{tabular}




\begin{tabular}{|c|c|c|c|c|c|c|c|c|c|}
\hline Asia & $\begin{array}{c}\text { China } \\
\text { India } \\
\text { Indonesia } \\
\text { Malaysia } \\
\text { Philippines } \\
\text { S. Korea } \\
\text { Taiwan } \\
\text { Thailand }\end{array}$ & $\begin{array}{l}1.40 \% \\
1.18 \% \\
1.43 \% \\
0.69 \% \\
1.20 \% \\
1.04 \% \\
0.82 \% \\
1.22 \%\end{array}$ & $\begin{array}{l}3.70 \% \\
3.36 \% \\
3.31 \% \\
2.07 \% \\
3.08 \% \\
3.16 \% \\
3.06 \% \\
3.41 \%\end{array}$ & $\begin{array}{l}1.59 \% \\
1.17 \% \\
1.53 \% \\
0.89 \% \\
1.23 \% \\
1.77 \% \\
1.52 \% \\
1.35 \%\end{array}$ & $\begin{array}{l}4.05 \% \\
3.37 \% \\
4.00 \% \\
2.73 \% \\
3.14 \% \\
4.47 \% \\
4.32 \% \\
4.04 \%\end{array}$ & $\begin{array}{l}1.17 \% \\
1.07 \% \\
1.29 \% \\
0.61 \% \\
1.05 \% \\
1.00 \% \\
0.70 \% \\
1.12 \%\end{array}$ & $\begin{array}{l}3.11 \% \\
2.93 \% \\
3.32 \% \\
1.81 \% \\
3.13 \% \\
2.77 \% \\
2.95 \% \\
3.13 \%\end{array}$ & $\begin{array}{l}1.48 \% \\
1.24 \% \\
1.49 \% \\
0.69 \% \\
1.27 \% \\
0.86 \% \\
0.70 \% \\
1.24 \%\end{array}$ & $\begin{array}{l}3.94 \% \\
3.60 \% \\
3.12 \% \\
2.04 \% \\
3.03 \% \\
3.03 \% \\
2.77 \% \\
3.41 \%\end{array}$ \\
\hline $\begin{array}{l}\text { Note: } 1 \\
\text { of vola } \\
\text { horizon } \\
\text { capture }\end{array}$ & $\begin{array}{l}\text { ble provides } \\
\text { re average } \\
\text { rs in the dec } \\
\text { lecomposed }\end{array}$ & $\begin{array}{l}\text { volat } \\
\text { ARCH } \\
\text { posed } \\
\text { ck retı }\end{array}$ & $\begin{array}{l}\text { neasu } \\
\text { ility } \\
\text { marl } \\
\text { or me }\end{array}$ & $\begin{array}{l}\text { across } \\
\text { ure fo } \\
\text { eturn } f \\
\tan 32\end{array}$ & $\begin{array}{l}1 \text { cou } \\
\text { time } \\
\text { ss tha } \\
\text { s }\end{array}$ & lays, & long & $\begin{array}{l}\text { gions. } \\
\text { The st } \\
\text { horiz }\end{array}$ & $\begin{array}{l}\text { e values } \\
\text { t term }\end{array}$ \\
\hline
\end{tabular}

Table 2: Volatility Measures across the emerging world

In the interest of robustness, we believe that findings based on full sample for 13 years, may provide misleading information since during this tenure, the equity markets globally experienced multiple ups and downs. For this case, our sample is divided into three phases and we study the volatility across these three phases. The findings of broken down sample provides evidence in line with earlier studies like Schwert (1989), who argues the stock market volatility proved to be counter-cyclical; where it was greater in recessionary periods than in expansions. While Backus and Kehoe (1992) reaffirmed the earlier beliefs and established that the correlation between stock market and industrial production cycles are significantly positive.

The first three years of sample period are 2001-2003, which experienced major accounting scandals, and the global markets were reeling from the World Trade Centre bombings (Johnston and Nedelescu, 2004). Interestingly we notice that the volatilities of all emerging markets are relatively less from the full sample period, but a stark difference can be noticed in the ranking. In Europe and African region, Egyptian market seems to be the least volatile, which may be owing to its stable economic conditions and liberalization policies. This is the period where the liberalization had helped the international investors to enter the market amid cautiously and liquidity had increased, but not excess yet.

Turkey showed immense volatility which has been documented by Arshad et al. (2014) as being caused by the massive currency fluctuation and inflation in the country. An interesting observation is the very high volatility in the case of Russia, which may have been caused by the economic and political uncertainty in the post-cold war era and the breakup of the USSR. Anatolyev (2005) and Goriaev and Sonin (2005) had found similar patterns in the case of Russian stock market. Their understanding is based on the deteriorating economic condition of the stock market and on the relative nascent stage of the stock market since it 
opened in 1984 only. Moving to the Asian region, the evidence suggests that in short term and long term fundamental based volatility, countries like Malaysia, India and Philippines experienced low volatility. This betterment of the volatility has been linked with the trading volume, which is based on investment flow in the market, and discussed extensively in Lamoureux and Lastrapes (1990). Sharma et al. (1996) and Pyun et al. (2000), who argue that increased trading volume reduces the volatility. Which is evident as the ASEAN region was just recovering post the Asian Financial crisis and there was a huge influx of foreign investors in the market to tap into the boom. While the Indian economy had recently liberalized in the 1990's and with a strong domestic market, the potential was huge. This attracted the inflow of portfolio funds in the market. This is evident through the near $40 \%$ increment in portfolio investment inflows to these countries over the three year period.

In the following period of 2003-2006, which is marked as global economic boom, a general realignment of the market volatilities can be witnessed, with a relatively stable decline across the emerging world. This is primarily credited to a financial markets surge globally, along with liquidity flow to the emerging markets, as the economies picked up. An interesting aspect is the jump in ranking for more stable European Union member countries, like Greece, Poland and Czech Republic. This decline in their volatilities goes back to the liberalization and economic linkage impact on stock market hypothesis discussed by Bekaert and Harvey (1995) and Peters (1996). With the elimination of country trade and investment barriers, and monetary union, with a general positive feel to the economics, these emerging markets of European Union, attracted funds, which helped in stabilizing the stock market, both in short term as well as long term volatility.

In the Asian region, the markets which went down in the ranking are Indonesia and Thailand, both on the shorter speculative end of the volatility as well as more fundamental based. This can primarily be attributed to the political and civil uncertainty prevailing in the country which kept the investors nervous throughout the major part of this sample period.

The economic slowdown initiated with the collapse of Lehmann Brothers in 2007, lead to an economic slowdown globally and tightening liquidity situation across globe in the financial markets. The economic slowdown has shown an increase in volatility on both short term and the longer spectrum for almost all the emerging countries. The most neutral effect can be witnessed in the Americas, where although the volatility has risen during 2007-2014, the ranking hasn't changed much, with the Chilean market staying least volatile on both short term and long term across the last decade and a half. This may be attributed to the stable nature of Chile's economy. 
The worst hit countries in terms of stock market volatility during this phase can be witnessed in terms of China and India in the Asia, and Greece, Russia, Hungary and Turkey in Europe. The primary reason for these countries is the strong interdependence to the developed markets, US primarily which resulted in contagion effect, both in short term and long term. This has been documented by Dewandaru et al. (2014) where they highlight the contagion effect of the financial crisis to these economies. The breakdown of the outflow of portfolio investments which created a liquidity crunch highlights the role of US and European based international funds.

This has further been deliberated later in the followings section on integration. Interestingly one country which relatively remained unscathed is Malaysia, which may be due to the decades of "look east" policy of Malaysian economic managers, which has changed the dependence dynamics of the Malaysian economy and financial markets. Although there are signs of increased volatility, but the increment is not very huge as well as the fact that it remains as one of the least volatile emerging markets in longer horizon and the least volatile in shorter horizon.

\subsection{Exploring Efficiency in Emerging Markets}

Our efficiency analysis initiates with the identification of apparent crossovers, of each curve for sample country for each time period concerned. Figure 1 presents the graphs for two countries as sample used for identification of crossover. Following the identification, we calculate the slope of the generalized Hurst exponents for short and long term as presented in Table 3 (Only the slope for 2003-2006 period is presented as sample). With the variation $q$ from -4 to 4 , we can observe that change of generalized Hurst exponents of two sub-series depends on q, providing evidence of the apparent multifractal nature of the market returns. As per author's knowledge, not many papers have explored the efficiency of stock markets using MFDFA. Amongst those, our results concur with those of Rizvi et al. (2014), Cajuero et al. (2009) and Arshad and Rizvi (2015). From Table 3, a moderate change in generalized Hurst exponents $\mathrm{h}(\mathrm{q})$ when $\mathrm{q}$ varies from -4 to 4 for both $\mathrm{S}<\mathrm{S}^{*}$ and $\mathrm{S}>\mathrm{S}^{*}$ can be observed, implying that the multifractality characteristic of the markets becomes weaker and also reflecting the markets as becoming relatively more efficient. 

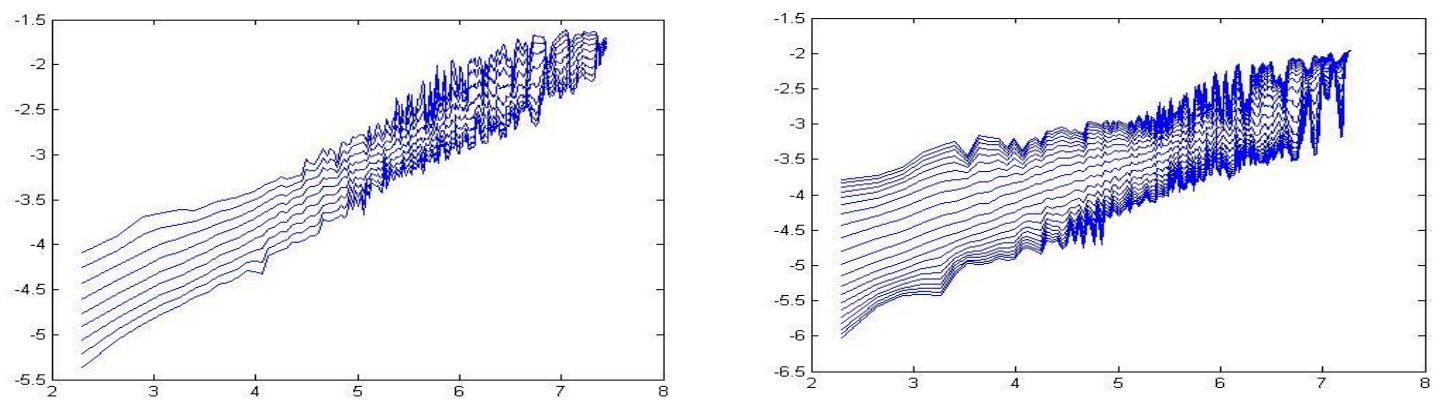

Figure 1: The curve of $\mathrm{Fq}(\mathrm{s})$ versus s in log-log plot for Korea (left) and India (right)

The multifractal analysis is conducted using a $q=4$, in light of the recent study of Jiang and Zhou (2007) who have explored the determination of the apparent $\mathrm{q}$ based on the divergence of the integrand for large $\mathrm{m}_{\mathrm{a}}$. (For a detailed discussion on determination of ' $\mathrm{q}$ ' see Jiang and Zhou, 2007; Zhou, et al., 2006 and Rizvi et al. 2014).

\begin{tabular}{|c|cc|cc|cc|cc|}
\cline { 2 - 9 } \multicolumn{1}{c|}{} & \multicolumn{2}{c|}{ MALAYSIA } & \multicolumn{2}{c|}{ CHILE } & \multicolumn{2}{c|}{ RUSSIA } & \multicolumn{2}{c|}{ EGYPT } \\
\cline { 2 - 9 } & $\begin{array}{l}\text { Short } \\
\text { Term }\end{array}$ & $\begin{array}{l}\text { Long } \\
\text { Term }\end{array}$ & $\begin{array}{l}\text { Short } \\
\text { Term }\end{array}$ & $\begin{array}{l}\text { Long } \\
\text { Term }\end{array}$ & $\begin{array}{c}\text { Short } \\
\text { Term }\end{array}$ & $\begin{array}{l}\text { Long } \\
\text { Term }\end{array}$ & $\begin{array}{l}\text { Short } \\
\text { Term }\end{array}$ & $\begin{array}{c}\text { Long } \\
\text { Term }\end{array}$ \\
\hline $\mathbf{- 4}$ & 0.650 & 0.554 & 0.636 & 0.607 & 0.672 & 0.515 & 0.656 & 0.848 \\
$\mathbf{- 3}$ & 0.637 & 0.544 & 0.624 & 0.585 & 0.642 & 0.511 & 0.634 & 0.822 \\
$\mathbf{- 2}$ & 0.628 & 0.539 & 0.613 & 0.562 & 0.613 & 0.513 & 0.610 & 0.791 \\
$\mathbf{- 1}$ & 0.619 & 0.542 & 0.604 & 0.540 & 0.586 & 0.524 & 0.583 & 0.753 \\
$\mathbf{0}$ & 0.605 & 0.546 & 0.600 & 0.521 & 0.557 & 0.539 & 0.556 & 0.710 \\
$\mathbf{1}$ & 0.582 & 0.543 & 0.600 & 0.505 & 0.522 & 0.545 & 0.529 & 0.666 \\
$\mathbf{2}$ & 0.545 & 0.529 & 0.604 & 0.492 & 0.474 & 0.524 & 0.502 & 0.625 \\
$\mathbf{3}$ & 0.498 & 0.510 & 0.610 & 0.482 & 0.422 & 0.486 & 0.472 & 0.591 \\
$\mathbf{4}$ & 0.451 & 0.488 & 0.616 & 0.472 & 0.380 & 0.444 & 0.438 & 0.562 \\
& & & & & & & & \\
\end{tabular}

Note: This table shows the generalized hurst exponents for short-term and long-tern using $\mathrm{q}=4$.

Not all countries are included in this paper for the sake of brevity. The results are available upon request.

Table 3: Generalized Hurst exponents for short term and long term

In line with the earlier theory outlined in literature review, for a market to be efficient, all fluctuations should follow random walk behaviour. This translates into $h(q)$ 's related to different q's are equal to 0.5. For our analysis, we focus on large and small fluctuations to define market deficiency measure as:

$$
D=\frac{1}{2}(|h(-4)-0.5|+|h(4)-0.5|)
$$

In Eq (23) scale exponents $\mathrm{h}(4)$ and $\mathrm{h}(4)$ are used for denoting the small and large price fluctuations. For a market to be efficient, the value of $D$ has to be close to 0 , whereas a large value of efficiency indicates a less efficient market. Our focus of the study is on the 
general efficiency of the market; hence the empirical analysis will focus on $D$ in short term and long term, and not indulge in small or large fluctuation.

Table 4 provides the efficiency ranking for full 13 year time period provides highlights which conform to recent literature which emphasize that that the development stage of the market also plays a role in the relative efficiency of the market. Appendix III provides the efficiency ranking for our sub divided time periods. We notice that in the emerging markets ranking the relative more stable economies Poland, Turkey and Malaysia stand out in shorter horizon, while China makes the cut for one of the more efficient markets on the fundamental based longer horizon. This can be attributed primarily to relative size and liquidity of these markets as well as stronger economic fundamentals of the country.

The efficiency ranking keeps it trend amongst the intra-regional ranking as well, with Poland and Turkey being most efficient for Europe while Malaysia, Taiwan and China for Asian region. The longer horizon efficiency ranking is derived more out of the fundamental view investor base, and tends to be more stable and founded in the longer term vision of the economy, while the shorter horizon can fluctuate owing to the liquidity crunches and speculative bubbles easily. The findings are generally in line with earlier studies on similar topic like Arshad and Rizvi (2015), Rizvi and Arshad (2017); Arshad et al. (2016) etc. At this juncture, noticeably the relationship of shorter term horizon seems inverse between efficiency and volatility nexus, which may be explained via the liquidity and herd mentality theories. The stocks markets which tend to become more liquid will tend to be more volatile in shorter horizon, thus deviating from the EMH through the herd mentality and also short term bubbles.

Table 4: Efficiency Ranking in Emerging Stock Markets

\begin{tabular}{rlrrllr} 
& & \multicolumn{3}{c}{ Full } \\
\hline \multicolumn{1}{r}{ Short term } & & & \multicolumn{2}{c}{ Long term } \\
1 & Poland - Eur. \& Afr. & 0.058 & 1 & Poland - Eur. \& Afr. & 0.015 \\
2 & Turkey - Eur. \& Afr. & 0.076 & 2 & China - Asia & 0.025 \\
3 & Malaysia - Asia & 0.099 & 3 & Malaysia - Asia & 0.033 \\
4 & Mexico - Amer. & 0.106 & 4 & Russia - Eur. \& Afr. & 0.035 \\
5 & Peru - Amer. & 0.107 & 5 & S. Africa - Eur. \& Afr. & 0.035 \\
6 & Greece - Eur. \& Afr. & 0.109 & 6 & Brazil - Amer. & 0.044 \\
7 & Hungary - Eur. \& Afr. & 0.111 & 7 & Mexico - Amer. & 0.046 \\
8 & Taiwan - Asia & 0.114 & 8 & Thailand - Asia & 0.055 \\
9 & Brazil - Amer. & 0.118 & 9 & India - Asia & 0.06 \\
10 & China - Asia & 0.129 & 10 & Turkey - Eur. \& Afr. & 0.065 \\
11 & South Korea - Asia & 0.134 & 11 & Philippines - Asia & 0.065
\end{tabular}

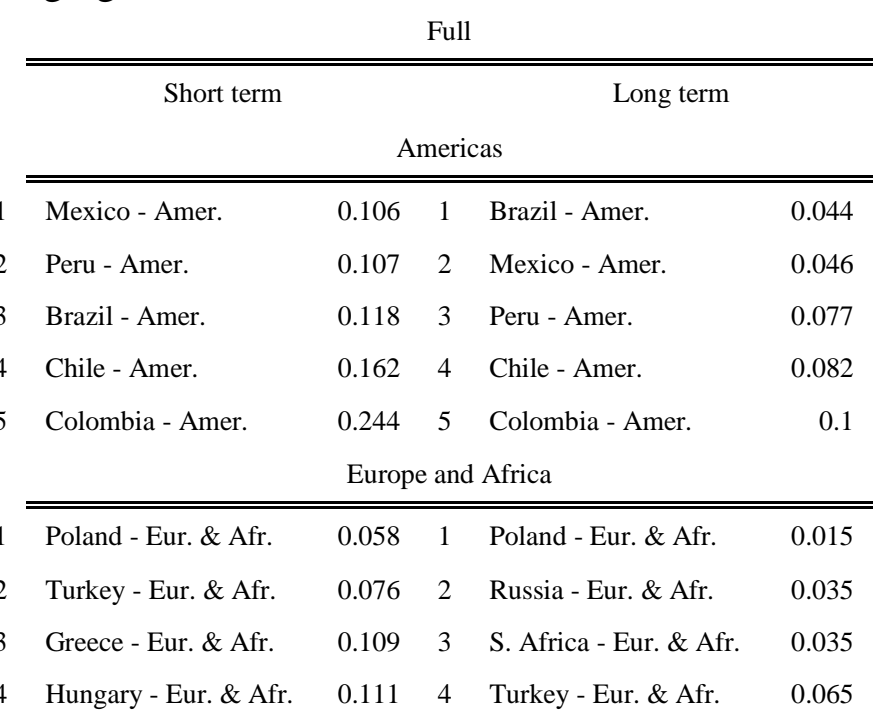




\begin{tabular}{|c|c|c|c|c|c|c|c|c|c|c|}
\hline Thailand - Asia & 0.135 & 12 & Hungary - Eur. \& Afr. & 0.075 & 5 & Russia - Eur. \& Afr. & 0.146 & 5 & Hungary - Eur. \& Afr. & 0.075 \\
\hline Russia - Eur. \& Afr. & 0.146 & 13 & Peru - Amer. & 0.077 & 6 & S. Africa - Eur. \& Afr. & 0.146 & 6 & Czech - Eur. \& Afr. & 0.082 \\
\hline S. Africa - Eur. \& Afr. & 0.146 & 14 & Indonesia - Asia & 0.079 & 7 & Czech - Eur. \& Afr. & 0.181 & 7 & Egypt - Eur. \& Afr. & 0.168 \\
\hline Chile - Amer. & 0.162 & 15 & Czech - Eur. \& Afr. & 0.082 & 8 & Egypt - Eur. \& Afr. & & 8 & Greece - Eur. \& Afr. & 0.205 \\
\hline India - Asia & 0.164 & 16 & Chile - Amer. & 0.082 & \multicolumn{6}{|c|}{ Asia } \\
\hline Philippines - Asia & 0.176 & 17 & South Korea - Asia & 0.098 & 1 & Malaysia - Asia & 0.099 & 1 & China - Asia & 0.025 \\
\hline Indonesia - Asia & 0.177 & 18 & Colombia - Amer. & 0.1 & 2 & Taiwan - Asia & 0.114 & 2 & Malaysia - Asia & 0.033 \\
\hline Czech - Eur. \& Afr. & 0.181 & 19 & Taiwan - Asia & 0.105 & 3 & China - Asia & 0.129 & 3 & Thailand - Asia & 0.055 \\
\hline \multirow[t]{5}{*}{ Colombia - Amer. } & 0.244 & 20 & Egypt - Eur. \& Afr. & 0.168 & 4 & South Korea - Asia & 0.134 & 4 & India - Asia & 0.06 \\
\hline & & 21 & Greece - Eur. \& Afr. & 0.205 & 5 & Thailand - Asia & 0.135 & 5 & Philippines - Asia & 0.065 \\
\hline & & & & & 6 & India - Asia & 0.164 & 6 & Indonesia - Asia & 0.079 \\
\hline & & & & & 7 & Philippines - As & 0.176 & 7 & South Korea - Asia & 0.098 \\
\hline & & & & & 8 & Indonesia - Asia & 0.177 & 8 & Taiwan - Asia & 0.105 \\
\hline
\end{tabular}

Table 4: Efficiency Ranking in Emerging Stock Markets

Note: This table ranks the countries according to their efficiency. The lower the efficiency value, the more efficient the market. The efficiency measure is calculated using mf-dfa for the time period under consideration. The short term horizon factors in the decomposed stock market return for less than 8 days, while long term horizon captures the decomposed stock returns for more than 32 days

In the early crisis of 2001-2002 and the following economic boom phase of 20032006, an interesting aspect of efficiency ranking is the relative higher efficiency of European emerging markets in shorter horizon, while in the longer term it's dominated by the Asian emerging markets. This may be attributed to the gradual financial liberalization policies in the Asian markets. Our findings are similar to what Cajueiro et al. (2009) found in the case of Greece, where they found evidence that each span of an economic upswing and the financial liberalization policies impact on higher efficiency and deduced a positive impact of financial liberalization on the market efficiency. While in the shorter horizon the liquidity in the European markets increased the available funds and pushed the markets up in the efficiency ranking, but longer term fundamental valuation based investment was attracted by the Asian market. This is also reflected partially in the global investment patterns.

The following time span of 2007-2014, which has been highlighted as the global economic slowdown, provides totally contrasting findings for the emerging markets in relation to previous time periods. Across the emerging markets the America's emerging markets surprisingly stand out amongst the highly efficient, mainly Peru and Mexico in the shorter and longer horizon respectively. This, in the view of authors may be attributed to the relative neutrality of these markets to global financial crisis, and the stronger domestic investor base. The ensuing financial crisis, wiped of billions of dollars of wealth from the 
developed markets, which put an immense pressure on the emerging stock markets, as global investment portfolios started squeezing their investments, and partial liquidation of emerging markets portfolios started to fund the losses made in developed markets. This liquidity crunch caused a contagion effect, but primarily in the shorter horizon. As the findings for efficiency measure indicate for majority of the emerging countries, the decline in efficiency measure from the preceding boom is large for short term, while neutral to small loss in efficiency in longer horizon. This phenomenon of liquidity and efficiency has also been discussed by Chordia et al. (2008).

\subsection{Integration with the World Market}

Recent studies have explored the integration phenomena of stock markets and they primarily argue that the deepening market integration increases the vulnerability of the market to external shocks. In regards to this, integration provides a unique aspect for studying the capital markets, and we therefore attempt to measure markets' co-movements as a proxy of their integration level. As per Bekaert \& Harvey, 1995; Bekaert et al., 2002; Baele, 2005; Bekaert et al., 2005, the more the markets tend to be integrated, the assets prices will be explained mostly by common factors so that a local market return would be determined by their covariances with other markets.

Table 5 provides a snapshot of the integration levels for the emerging markets under study, we observe some unique patterns, especially in relation to the linkages with volatility and efficiency findings. The integration level for the full period provides an interesting insight regarding the regional segregation. Asian emerging markets tend to have relatively less integration with the world market over the whole period on an average as compared to the Americas and Europe. The possibility to this phenomena is owing to the relative trade linkages of the developed world with the emerging markets. In the earlier part of the decade under study, the focus of trade based linkage.

The linkage of trade and integration and its economic growth has been discussed Bekaert et al., 2005, Rajan and Zingales, 2003; Gourinchas and Jeanne, 2006; and others and they argue integration and trade play an essential role in boosting economic growth, improving factor productivity, reducing the cost of capital, promoting better corporate governance and increasing size and liquidity.

Similar to previous discussion, we analyse the integration broken down, into two horizons, and for different phases. This helps in distinguishing between speculation based and fundamental based similar to Bodart and Candelon (2009) and Orlov (2009) that examined 
contagion by associating high and low frequencies with contagion and interdependence. A trend that is visible across the segregated period, is an overall increasing trend in integration over the duration for all emerging countries. The year 2001-2002, shows evidence of pretty low integration in the shorter horizon for Asian countries, with the East Asian economies Philippines, Malaysia and Thailand who were reeling from Asian financial crisis having the lowest integration.

The other countries from Europe and African group, Turkey and Egypt, also exhibiting low integration at the short term level, were also hit by internal crisis. An aspect which may be inferred from this and the relatively higher integration in the longer term reflects, that during the period, the linkages with the world market was primarily based on fundamental valuations, and not much speculative and short term investment traces were present. But this does not hold strong for two countries Brazil and Mexico in Americas, which owing to their location and liberalization in 1990s were strongly integrated with the world market. This is in line with a recent study by Dewandaru et al. (2014) who find similar market integration pattern using an ICAPM methodology.

\begin{tabular}{|c|c|c|c|c|c|c|c|c|c|}
\hline & \multirow{2}{*}{\multicolumn{2}{|c|}{ 2001-2014 }} & \multirow{2}{*}{\multicolumn{2}{|c|}{$2001-2003$}} & \multirow{2}{*}{\multicolumn{2}{|c|}{ 2003-2006 }} & \multirow{2}{*}{\multicolumn{2}{|c|}{ 2006-2014 }} \\
\hline & & & & & & & & & \\
\hline \multirow[b]{2}{*}{ AMERICAS } & & ST & LT & ST & LT & ST & LT & ST & LT \\
\hline & $\begin{array}{c}\text { Brazil } \\
\text { Chile } \\
\text { Colombia } \\
\text { Mexico } \\
\text { Peru }\end{array}$ & $\begin{array}{l}0.4773 \\
0.3403 \\
0.1916 \\
0.4949 \\
0.3529\end{array}$ & $\begin{array}{c}0.5312 \\
0.3857 \\
0.2375 \\
0.535 \\
0.3734\end{array}$ & $\begin{array}{l}0.2587 \\
0.2257 \\
0.0038 \\
0.3856 \\
0.0159\end{array}$ & $\begin{array}{l}0.2701 \\
0.2432 \\
0.0157 \\
0.3787 \\
0.0374\end{array}$ & $\begin{array}{c}0.421 \\
0.2519 \\
0.0633 \\
0.4658 \\
0.1839\end{array}$ & $\begin{array}{l}0.4839 \\
0.3056 \\
0.1421 \\
0.5308 \\
0.2032\end{array}$ & $\begin{array}{l}0.5694 \\
0.4222 \\
0.3185 \\
0.5414 \\
0.5417\end{array}$ & $\begin{array}{l}0.6298 \\
0.4706 \\
0.3528 \\
0.5802 \\
0.5628\end{array}$ \\
\hline \multirow[b]{2}{*}{$\begin{array}{c}\text { EUROPE AND } \\
\text { AFRICA }\end{array}$} & & ST & LT & ST & LT & ST & LT & ST & LT \\
\hline & $\begin{array}{c}\text { Czech } \\
\text { Egypt } \\
\text { Greece } \\
\text { Hungary } \\
\text { Poland } \\
\text { Russia } \\
\text { S. Africa } \\
\text { Turkey }\end{array}$ & $\begin{array}{l}0.2638 \\
0.0156 \\
0.2723 \\
0.3031 \\
0.3507 \\
0.3509 \\
0.3252 \\
0.2881\end{array}$ & $\begin{array}{l}0.2772 \\
0.0341 \\
0.3109 \\
0.3446 \\
0.3963 \\
0.3952 \\
0.3764 \\
0.3085\end{array}$ & $\begin{array}{l}0.1751 \\
0.0236 \\
0.1861 \\
0.1829 \\
0.1698 \\
0.1654 \\
0.2172 \\
0.1061\end{array}$ & $\begin{array}{l}0.1675 \\
0.0414 \\
0.1951 \\
0.2212 \\
0.2018 \\
0.1881 \\
0.2289 \\
0.1202\end{array}$ & $\begin{array}{l}0.1685 \\
0.0062 \\
0.2149 \\
0.1613 \\
0.2129 \\
0.1711 \\
0.1997 \\
0.1614\end{array}$ & $\begin{array}{c}0.1933 \\
0.0282 \\
0.233 \\
0.1793 \\
0.2671 \\
0.2326 \\
0.279 \\
0.1622\end{array}$ & \begin{tabular}{c|}
0.3426 \\
0.0388 \\
0.3288 \\
0.417 \\
0.4791 \\
0.5045 \\
0.4264 \\
0.4103
\end{tabular} & $\begin{array}{l}0.3551 \\
0.0904 \\
0.3871 \\
0.4727 \\
0.5233 \\
0.5447 \\
0.4723 \\
0.4437\end{array}$ \\
\hline \multirow[b]{2}{*}{ ASIA } & & ST & LT & ST & LT & ST & LT & ST & LT \\
\hline & $\begin{array}{c}\text { China } \\
\text { India } \\
\text { Indonesia } \\
\text { Malaysia } \\
\text { Philippines } \\
\text { S. Korea } \\
\text { Taiwan } \\
\text { Thailand }\end{array}$ & $\begin{array}{c}0.2161 \\
0.1836 \\
0.1577 \\
0.0978 \\
0.0417 \\
0.1829 \\
0.1422 \\
0.137\end{array}$ & $\begin{array}{c}0.5181 \\
0.5493 \\
0.3775 \\
0.3202 \\
0.39 \\
0.5454 \\
0.4876 \\
0.4891\end{array}$ & $\begin{array}{c}0.1067 \\
0.0887 \\
0.0631 \\
0.0164 \\
0.0345 \\
0.119 \\
0.0322 \\
0.091\end{array}$ & $\begin{array}{c}0.5692 \\
0.3563 \\
0.2259 \\
0.1785 \\
0.12 \\
0.5344 \\
0.1686 \\
0.2736\end{array}$ & $\begin{array}{c}0.1568 \\
0.1022 \\
0.122 \\
0.0452 \\
0.0093 \\
0.1397 \\
0.1156 \\
0.0845\end{array}$ & $\begin{array}{c}0.3888 \\
0.411 \\
0.3507 \\
0.2233 \\
0.3419 \\
0.4319 \\
0.4621 \\
0.4054\end{array}$ & \begin{tabular}{c|}
0.28 \\
0.2561 \\
0.2041 \\
0.1592 \\
0.0621 \\
0.2252 \\
0.1875 \\
0.1796
\end{tabular} & $\begin{array}{c}0.578 \\
0.6813 \\
0.5582 \\
0.4143 \\
0.5574 \\
0.6133 \\
0.5897 \\
0.596\end{array}$ \\
\hline
\end{tabular}


Table 5: Integration Levels for Emerging Markets

In the following two periods, we notice that in the economic boom, saw the rise in the integration level for most of the Asian emerging countries, as they provided stronger fundament based valuation and huge untapped market potential. Most of the Asian economies like China, South Korea, Indonesia, India and Taiwan underwent regulatory improvements and further liberalizations in capital markets proving to be stronger linkage on shorter end of the spectrum. While an overall economic boom in the world saw trade increments, and stronger fundamental based integration in the long term component. While the same trend holds in the European, American and African emerging markets, the main beneficiaries seem to be the Euro monetary union economies, where the fundamental integration jumped. While in the case of Mexico and Brazil, the jump can be attributed to the regional development, as well as the World Trade Policy started becoming effective across the world providing access to Brazilian and Mexican economies to tap into the world markets and attract investments into their capital markets.

In the following crisis period of 2007-2013, we find evidence that for both the shortterm and long-term investors, the integration levels with the world tends to increase in economic downturns similar to earlier findings of Dewandaru et al. (2014). The higher integration can be caused due to the nature of the modern trade and financial markets, which have liberalized and become more integrated. This also represents a high presence of financial contagion which may be due to the trade and economic integration similar to findings of Arshad et al. (2014).

\subsection{Nexus Studies of Three Parameters of Emerging Stock Markets}

Amongst the parameters we have discussed in our study, some elements of correlations seems to exist amongst them. Two questions arise at this juncture; (1) Does volatility affect the inefficiency and to what extent? (2) Does the volatility and integration nexus exists and to what extent?

Since our analysis focuses purely on emerging markets, a pitfall that needs to be taken care of is the impact of the financial liberalization and stage of market development which contributes to the overall investor base and multitude of other stock market development indicators. The literature on stock market development discusses governance and financial liberalization as a key aspect of market development as highlighted by Barro (1997) and Shleifer and Wolfenson (2002). While, Rousseau and Wachtel (2000), Beck and Levine, 
(2005) and Caporale and Howells (2004) build a case for effective resource allocation to the stage of market development.

In light of this, we test two relationships, firstly if there exists as a link between market volatility and efficiency similar, while controlling for stock market development stage, using the proxy of Turnover Ratio. Secondly we explore whether integration and volatility have some interacting relationship since earlier it has been discussed, that higher integration and higher volatility may be interlinked for some countries. The relationship which we explore can be expressed as:

$$
\begin{aligned}
& \text { Efficiency }_{i t}=\alpha+\text { Volatility }_{i t}+S M D_{i t}+\epsilon_{i t} \\
& \text { Integration }_{i t}=\alpha+\text { Volatility }_{i t}+S M D_{i t}+\epsilon_{i t}
\end{aligned}
$$

Employing a pooled OLS regression ${ }^{2}$ corrected for standard error of efficiency as the dependent variable on stage of market development, the Table 6 reports the output for both nexuses. The results highlight concurrence with earlier literature and show a significant positive impact of lower volatility on efficiency (since lower the efficiency score, the better) in long term only. This may be due to the nature of these markets, or the composition of the short term versus long term investor.

In regards to the nexus between the integration and volatility parameters of emerging stock market, we found interesting findings for our nexus as reported in table 6 . In the shorter horizon the higher volatility in an emerging market would result in a lower integration while the inverse of this is observed in longer term component. This may be attributing due to the emerging nature of the markets, where primary shorter horizon investors are domestic and may operate in an environment secluded from world market behaviour. While at the longer horizon, fundamental linkages and longer horizon international investors come in play which may provide more stability in that horizon.

\begin{tabular}{|c|c|c|c|}
\hline \multicolumn{4}{|c|}{ Efficiency and Volatility } \\
\hline & Constant & Volatility & Stock Market Development \\
\hline \multirow{3}{*}{ Short Term } & $\begin{array}{c}0.0134 \\
(0.001)^{*}\end{array}$ & $\begin{array}{c}0.3472 \\
(0.102)\end{array}$ & $\begin{array}{c}-0.0935 \\
(0.3815)\end{array}$ \\
\hline \multirow{3}{*}{ Long Term } & $\begin{array}{c}0.4678 \\
(0.000)^{*}\end{array}$ & $\begin{array}{c}0.0087 \\
(0.019)^{* *}\end{array}$ & $\begin{array}{c}0.0465 \\
(0.172)\end{array}$ \\
\hline
\end{tabular}

\footnotetext{
${ }^{2}$ We have used pooled OLS regressions, as our measured variables have different time windows. While GMM can be a potential method which also takes care of endogeneity issue, the $\mathrm{N}$ we have is 21 , which as per the design of GMM is too low and may have biased results.
} 


\begin{tabular}{|c|c|c|c|}
\hline \multicolumn{4}{|c|}{ Integration and Volatility } \\
\hline & Constant & Volatility & Stock Market Development \\
\hline Short Term & $\begin{array}{c}0.0042 \\
(0.000)^{*}\end{array}$ & $-0.1465(0.002)^{*}$ & $\begin{array}{c}0.0152 \\
(0.005)^{*}\end{array}$ \\
\hline Long Term & $\begin{array}{c}0.3425 \\
(0.002)^{*}\end{array}$ & $0.4567(0.009)^{*}$ & $\begin{array}{l}0.1987 \\
(0.231)\end{array}$ \\
\hline \multicolumn{4}{|c|}{$\begin{array}{l}\text { Note: Pooled OLS regression is run on Efficiency and Volatility nexus and then on } \\
\text { Integration and Volatility. The regression is run separately for short term and long } \\
\text { term. } \\
\text { The values in parenthesis represents the p value with significance at } 1 \%, 5 \% \text { and } \\
10 \% \text { represented by } *, * *, * * * \text { respectively. }\end{array}$} \\
\hline
\end{tabular}

Table 7: Pooled OLS Regression of Efficiency Volatility and Integration Parameters

\subsection{Conclusion}

In the case of emerging markets, our study of the three key parameters; volatility, efficiency and integration of the stock markets provides interesting insights into the structure of emerging markets in relation to their regional counterparts and across regions. The findings of the papers hold key implications for regulators and global investors for investment strategies and theory for academic literature. As per author's knowledge, only a handful of studies in the existing literature have provided proof on the linkage of the three parameters of stock market with each other and across the economic stages. This study furthers the literature on emerging stock markets and according to our knowledge is the only one which studies such diverse markets across regions for links with efficiency, volatility and integration across business cycles.

The results of our research put forth an argument of enhancing integration across the last decade, combined with a unique relationship with volatility. This can be explained by the financial liberalization that took place in the emerging markets during the course of the last decade and a half. The phenomena of an increasing volatility impacts the integration negatively in the shorter horizon component of the emerging markets while a positive relationship exists in longer term.

In respect to the efficiency, the earlier phases provide evidence of relative higher efficiency of European emerging markets in shorter horizon, while in the longer term it's dominated by the Asian emerging markets owing to the liberalization policies in the Asian markets. While in the crisis period partial liquidation of emerging markets portfolios started created inefficiencies in the shorter horizon through contagion except the American emerging markets.

From the aspect of economic managers, the emerging markets which have pursued liberalization and more fundamental based linkages provide, a less volatile, better integrated 
and efficient market. These markets can help in the development of the economy, via resource allocation and capital formation, and distribution of wealth channels. From an international investor perspective, the lower integration in shorter horizon allows the diversification of portfolios, while a stronger and improving integration in the longer term allows them to invest in real sector of the emerging economies. While our findings have made an attempt at understanding the linkages, for future research a dynamic model can be used which can take care of probably endogeneity problems and further refine the findings.

From a sustainable economic growth perspective for the emerging markets, it's a difficult situation for the policy makers, as a relatively higher longer horizon integration will increase the volatility of the market which would reduce efficiency. But primarily for the sustainability aspect the policy makers need to address the concerns of the investors focused on long term, and move towards structural changes which governs their investment behaviour.

Our study has made a humble attempt at fulfilling a gap in the emerging market's stock market literature by exploring the troika of efficiency, volatility and integration. The study contributes in a better understanding of the behaviour is these markets both from an academic interest as well as an industry aspect. 


\section{References}

1. Alexander, C. (2009), Practical Financial Econometrics. John Wiley \& Sons, NY.

2. Anatolyev, S., (2005), A ten-year retrospection of the behavior of Russian stock returns, working paper, New Economic School.

3. Antonios, A. (2010), Stock Market and Economic Growth: An Empirical Analysis for Germany. Business and Economics Journal, 2010(BEJ-1).

4. Arshad, S., Rizvi, S.A.R., (2015). The troika of business cycle, efficiency and volatility. An East Asian perspective. Physica A: Statistical Mechanics and its Applications, 419, pp. $158-170$.

5. Arshad, S., Rizvi, S.A.R. and Ibrahim, M.H. (2014). Tripartite analysis across business cycles in Turkey: A multi-timescale inquiry of efficiency, volatility and integration. Borsa Istanbul Review, 14(4). 224-235.

6. Backus, D. K., and Kehoe, P. J. (1992). On the denomination of government debt: A critique of the portfolio balance approach. Journal of Monetary Economics, 23(3), pp. 359-376.

7. Baele, L. (2005). Volatility spillover effects in European equity markets. Journal of Financial and Quantitative Analysis, 40(02), pp. 373-401.

8. Batten, J.A., Kinateder, H., and Wagner, N. (2014). Multifractality and value-at-risk forecasting of exchange rates. Physica A: Statistical Mechanics and its Applications, 401, pp. $71-81$.

9. Bauwens, L., Laurent, S., and Rombouts, J. V. K. (2006). Multivariate GARCH models: a survey. Journal of Applied Econometries, 21(1), 79-109.

10. Beck, T., and Levine, R. (2005). Legal institutions and financial development. In: Menard, C., Shirley, M. (Eds.), Handbook for New Institutional Economics. Kluwer Academic Publishers, Norwell, MA.

11. Bekaert, G., Harvey, C.R., and Lundblad, C., (2005). Does financial liberalization spur growth? J. Financ. Econ. 77 (1), pp. 3-55.

12. Bekaert, Geert, Campbell R. Harvey, and Christian Lundblad, (2007), Liquidity and expected returns: Lessons from emerging markets, Review of Financial Studies 20, pp. 1783-1831.

13. Binswanger, M., (2000), Stock market booms and real economic activity: Is this time different? International Review of Economics \& Finance 9(4), pp.387-415.

14. Bodart, V., and Candelon, B., (2009). Evidence of interdependence and contagion using a frequency domain framework. Emerg. Mark. Rev. 10 (2009), 140-150. 
15. Bollerslev, T. (1990). Modelling the coherence in short-run nominal exchange rates: a multivariate generalized ARCH model. Review of Economic \& Statistics, 72(3), 498-505.

16. Caetono, M.A.L., and Yoneyama, T. (2012). A method for detection of abrupt changes in the financial market combining wavelet decomposition and correlation graphs. Physica A, $391(20), 4877-4882$

17. Cajueiro, D.O., Gogas, P., and Tabak, B.M., (2009). Does financial market liberalization increase the degree of market efficiency? The case of the Athens stock exchange. International Review of Financial Analysis, 18(1), pp. 50-57.

18. Caporale, G.M., Howells, P.G.A., and Soliman, A.M., (2004), Stock Market Development And Economic Growth: The Causal Linkage Journal Of Economic Development 29(1).

19. Chordia, T., Roll, R. and Subrahmanyam, A. (2008), Liquidity and market efficiency. Journal of Financial Economics, 87(2), pp. 249-268.

20. Dewandaru, G., Masih, R., Bacha, O.I., Masih, M. (2015). Combining momentum, value, and quality for the Islamic equity portfolio: Multi-style rotation strategies using augmented Black Litterman factor model. Pacific-Basin Finance Journal, 34, pp. 273-292

21. Dewandaru, G., Rizvi, S.A.R., Masih, R., Masih, M., Alhabshi, S.O. (2014a), What factors Explains stock market retardations in Islamic Countries? Emerging market Review, 19, pp. 106-127.

22. Dewandaru, G., Rizvi, S.A.R., Masih, R., Masih, M., and Alhabshi, S.O. (2014b), Stock market co-movements: Islamic versus conventional equity indices with multi-timescales analysis. Economic Systems. 38, pp. 553-571.

23. Dutta, S., Ghosh, D., and Samanta, S. (2014). Multifractal detrended cross-correlation analysis of gold price and SENSEX. Physica A. 413, 195-204.

24. Engle, R. (2002). Dynamic conditional correlation: a simple class of multivariate generalized autoregressive conditional heteroskedasticity models. Journal of Business \& Economic Statistics, 20(3), pp. 339-350.

25. Fama, E.F., (1990), Term-Structure Forecast of Interest Rates, Inflation, and Real Returns. Journal of Monetary Economics, 25(1), pp. 59-76.

26. Goriaev, A., and Sonin, K., (2005), Is political risk company-specific? The market side of the Yukos affair, working paper, New Economic School.

27. Gourinchas, P.-O., and Jeanne, O., (2006). The elusive gains from international financial integration. Rev. Econ. Stud. 73 (3), pp. 715-741. 
28. Greenspan, A., (2000), Global Challenges. C. o. F. Relations, Financial Crisis Conference. New York

29. Griffin, J.M, Kelly, P.J., and Nardari, F. (2010). Do Market Efficiency Measures Yield Correct Inferences? A Comparison of Developed and Emerging Markets. Rev. Financ. Stud. 22.

30. Hammoudeh, S., and Choi, K., 2007. Characteristics of permanent and transitory returns in oil sensitive emerging stock markets: the case of GCC countries. J. Int. Financ. Mark. Inst. Money. 17 (3), pp. 231-245.

31. Hammoudeh, S., Yuan, Y., McAleer, M., 2009. Shock and volatility spillovers among equity sectors of the Gulf Arab stock markets. Q. Rev. Econ. Financ. 49 (3), pp. 829-842.

32. Jiang, Z-Q, and Zhou, W-Z (2010), Complex stock trading network among investors. Physica A, 389(21), pp. 4929-4941.

33. Johnston, R., Nedelescu, O., (2005). The Impact of Terrorism on Financial Markets, Working Paper, International Monetary Fund, Washington.

34. Kantelhardt, J. W., Zschiengerm, S. A., Koscienly-Bunde, E., Havlin, S., Bunde, A., \& Stanley, H. E. (2002). Multifractal detrended fluctuation analysis of nonstationary time series. Physica A, 316, pp. 87-114.

35. Kim, S., Moshirian, F., Wu, E., (2006). Evolution of international stock and bond market integration: Influence of the European Monetary Union. J. Bank. Finance. 30, pp. 15071534.

36. Lamoureux C.G., Lastrapes, W.D. (1990). Heteroskedasticity in Stock Return Data: Volume versus GARCH Effects. Journal of Finance, 45, pp.221-229.

37. Larrain, B., (2004), Financial development, financial constraints, and the volatility of industrial output. Public Policy Discussion Paper 04-6, Federal Reserve Bank of Boston.

38. Mills, T.C. (2000), Business Cycle volatility and economic growth: a reassessment', Journal of Post Keynesian Economics, 23(1), pp.107-116.

39. Orlov Alexei, G., (2009). A cospectral analysis of exchange rate comovements during Asian financial crisis. J. Int. Financ. Mark. Inst. Money 19 (5), pp. 742-758.

40. Piyapas, T., (2007), Capital Market and Business Cycle Volatility, MPRA Paper No. 5188.

41. Pyun C. S., Lee, S.Y., Nam, K. 2000. Volatility and Information Flows in Emerging Equity Market - A Case of the Korean Stock Exchange. International Review of Financial Analysis, 9, pp. 405-420. 
42. Rajan, R.G., Zingales, L., (2003). The great reversals: the politics of financial development in the twentieth century. J. Financ. Econ. 69 (1), pp 5-50.

43. Rizvi, S.A.R., Arshad, S., Alam, N. (2015). Crises and Contagion in Asia Pacific Islamic v/s Conventional Markets. Pacifc-Basin Finance Journal, 34, pp. 315-326.

44. Rizvi, S.A.R., Dewandaru, G., Bacha, O.I., Masih, M., (2014), An analysis of stock market efficiency: Developed vs Islamic stock markets using MF-DFA. Physica A: Statistical Mechanics and its Applications 407, pp. 86-99.

45. Rousseau, P. L. and Wachtel, P., (2000). Equity markets and growth: Cross-country evidence on timing and outcomes, 1980-1995. Journal of Banking \& Finance, 24(12), pp. 1933-1957.

46. Schwert, G. W. (1989). Why Does Stock Market Volatility Change over Time? Journal of Finance, 44(5), pp. 1115-53.

47. Selçuk, F. (2004). Financial earthquakes, aftershocks and scaling in emerging stock markets. Physica A: Statistical Mechanics and its Applications, 333(C), pp. 306-316.

48. Sharma J.L., Mougoue, M., Kamath. R. (1996). Heteroskedasticity in Stock Market Indicator Return Data: Volume versus GARCH Effects. Applied Financial Economics., 6, pp. 337-342.

49. Shleifer, A., and Wolfenzon, D., (2002), Investor protection and equity markets. Journal of Financial Economics, 66(1), pp. 3-27.

50. Siliverstovs, B., and Duong, M. H. (2006). On the Role of Stock Market for Real Economic Acitivity: Evidence for Europe. Berlin: DIW Berlin, German Institute for Economic Research, Discussion paper 559.

51. Zhou, W.-X., Sornette, D. and Yuan, W.K. (2006), Inverse statistics and multifractality of exit distances in 3D fully developed turbulence, Physica D 214, pp.55-62

52. Yu, J., Hassan, M., (2008). Global and regional integration of the Middle East and North African (MENA) stock markets. Q. Rev. Econ. Finance. 48, 482-504.

53. Kang, S.H. and Yoon, S-M. (2011). The Global Financial Crisis and the Integration of Emerging Stock Markets in Asia. Journal of East Asian Economic Integration 15(4), pp. 49-71

54. Wai, D., and Cheung, W. (2000). The Impulse of Stock Market Volatility and the Market Crash of October 1987. Journal of Business Finance \& Accounting

55. Hooy, C-W and Lim, K-P (2013). Is market integration associated with informational efficiency of stock markets? Journal of Policy Modeling, 35(1), pp. 29-44. 
56. Rockinger, M. and Urga, G. (2001). A time-varying parameter model to test for predictability and integration in the stock markets of transition economies. Journal of Business and Economic Statistics, 19, pp. 73-84.

57. Schotman, P.C. and Zalewska, A. (2006). Non-synchronous trading and testing for market integration in Central European emerging markets. Journal of Empirical Finance, 13, pp. 462-494.

58. Alam, N., Arshad, S., and Rizvi, S.A.R. (2016). Do Islamic Stock Indices Perform better than Conventional Counterparts? An Empirical Investigation of Sectoral Efficiency. Review of Financial Economics (Forthcoming).

59. Laopodis, N.T. (2004). Financial market liberalization and stock market efficiency: Evidence from the Athens Stock Exchange. Global Finance Journal, 15(2), pp. 103-123.

60. Karim, B. A. and Ning, H.X. (2013). Driving forces of the ASEAN-5 stock markets integration. Asia-Pacific Journal of Business Administration, 5(3), pp.186 - 191. 
Appendix I. Key Economic Measures of Different Periods.

\begin{tabular}{|c|c|c|c|c|}
\hline \multicolumn{5}{|c|}{ 2001-2002 } \\
\hline & GDP Growth & Market Size/GDP & Liquidity & Currency \\
\hline Americas & \multirow{6}{*}{$\begin{array}{c}1.9 \% \\
2.0 \% \\
2.8 \% \\
2.1 \% \\
-0.2 \% \\
3.0 \% \\
\end{array}$} & \multirow{6}{*}{$\begin{array}{l}30.4 \% \\
29.1 \% \\
72.4 \% \\
11.7 \% \\
15.7 \% \\
23.1 \% \\
\end{array}$} & \multirow{6}{*}{$\begin{array}{c}15.5 \% \\
31.3 \% \\
6.6 \% \\
2.8 \% \\
28.0 \% \\
8.5 \% \\
\end{array}$} & \multirow{6}{*}{$\begin{array}{l}\text { Floating } \\
\text { Floating } \\
\text { Floating } \\
\text { Floating } \\
\text { Floating } \\
\end{array}$} \\
\hline Brazil & & & & \\
\hline Chile & & & & \\
\hline Colombia & & & & \\
\hline Mexico & & & & \\
\hline Peru & & & & \\
\hline Europe and Africa & \multirow{9}{*}{$\begin{array}{l}2.8 \% \\
2.3 \% \\
3.0 \% \\
3.4 \% \\
4.1 \% \\
1.3 \% \\
4.9 \% \\
3.2 \% \\
0.2 \%\end{array}$} & \multirow{9}{*}{$\begin{array}{c}39.9 \% \\
16.7 \% \\
27.3 \% \\
54.3 \% \\
19.4 \% \\
14.0 \% \\
30.4 \% \\
137.4 \% \\
19.3 \%\end{array}$} & \multirow{9}{*}{$\begin{array}{l}49.3 \% \\
40.6 \% \\
12.4 \% \\
35.0 \% \\
46.8 \% \\
23.6 \% \\
37.9 \% \\
44.5 \% \\
153.8 \%\end{array}$} & \multirow{9}{*}{$\begin{array}{c}\text { Floating } \\
\text { Floating } \\
\text { Currency Union } \\
\text { Currency Union } \\
\text { Floating } \\
\text { Floating } \\
\text { Floating } \\
\text { Floating }\end{array}$} \\
\hline Czech Republic & & & & \\
\hline Egypt, Arab Rep. & & & & \\
\hline Greece & & & & \\
\hline Hungary & & & & \\
\hline Poland & & & & \\
\hline Russian Federation & & & & \\
\hline South Africa & & & & \\
\hline Turkey & & & & \\
\hline Asia & \multirow{8}{*}{$\begin{array}{l}4.7 \% \\
8.7 \% \\
4.3 \% \\
4.1 \% \\
3.0 \% \\
3.3 \% \\
6.0 \% \\
3.7 \%\end{array}$} & \multirow{8}{*}{$\begin{array}{c}46.7 \% \\
35.7 \% \\
23.7 \% \\
14.8 \% \\
126.1 \% \\
51.2 \% \\
41.1 \% \\
33.9 \% \\
\end{array}$} & \multirow{8}{*}{$\begin{array}{c}112.2 \% \\
74.4 \% \\
178.1 \% \\
44.0 \% \\
20.1 \% \\
8.5 \% \\
348.4 \% \\
111.9 \%\end{array}$} & \multirow{8}{*}{$\begin{array}{l}\text { Fixed } \\
\text { Floating } \\
\text { Floating } \\
\text { Fixed } \\
\text { Floating } \\
\text { Floating* } \\
\text { Floating }\end{array}$} \\
\hline China & & & & \\
\hline India & & & & \\
\hline Indonesia & & & & \\
\hline Malaysia & & & & \\
\hline Philippines & & & & \\
\hline Korea, Rep. & & & & \\
\hline Thailand & & & & \\
\hline \multicolumn{5}{|c|}{ 2003-2006 } \\
\hline & GDP Growth & Market Size/GDP & Liquidity & Currency \\
\hline Americas & \multirow{6}{*}{$\begin{array}{l}4.6 \% \\
3.5 \% \\
5.0 \% \\
5.2 \% \\
3.4 \% \\
5.7 \%\end{array}$} & \multirow{6}{*}{$\begin{array}{c}52.0 \% \\
52.8 \% \\
112.4 \% \\
25.6 \% \\
25.8 \% \\
43.3 \%\end{array}$} & \multirow{6}{*}{$\begin{array}{c}19.2 \% \\
37.0 \% \\
13.6 \% \\
12.7 \% \\
25.7 \% \\
7.0 \%\end{array}$} & \multirow{6}{*}{$\begin{array}{l}\text { Floating } \\
\text { Floating } \\
\text { Floating } \\
\text { Floating } \\
\text { Floating }\end{array}$} \\
\hline Brazil & & & & \\
\hline Chile & & & & \\
\hline Colombia & & & & \\
\hline Mexico & & & & \\
\hline Peru & & & & \\
\hline Europe and Africa & \multirow{8}{*}{$\begin{array}{l}5.4 \% \\
5.5 \% \\
4.7 \% \\
4.6 \% \\
4.2 \% \\
4.6 \% \\
7.3 \% \\
4.6 \% \\
7.5 \%\end{array}$} & \multirow{8}{*}{$\begin{array}{c}64.3 \% \\
25.8 \% \\
64.3 \% \\
60.0 \% \\
28.3 \% \\
29.8 \% \\
69.4 \% \\
208.7 \% \\
27.9 \%\end{array}$} & \multirow{8}{*}{$\begin{array}{l}65.5 \% \\
79.9 \% \\
31.8 \% \\
47.6 \% \\
68.7 \% \\
34.5 \% \\
50.3 \% \\
44.7 \% \\
166.8 \%\end{array}$} & \multirow{8}{*}{$\begin{array}{c}\text { Floating } \\
\text { Floating } \\
\text { Floating } \\
\text { Currency Union } \\
\text { Currency Union } \\
\text { Floating } \\
\text { Floating } \\
\text { Floating } \\
\text { Floating } \\
\end{array}$} \\
\hline Czech Republic & & & & \\
\hline Egypt, Arab Rep. & & & & \\
\hline Greece & & & & \\
\hline $\begin{array}{c}\text { Hungary } \\
\text { Poland }\end{array}$ & & & & \\
\hline $\begin{array}{l}\text { Poland } \\
\text { Russian Federation }\end{array}$ & & & & \\
\hline South Africa & & & & \\
\hline Turkey & & & & \\
\hline Asia & $6.6 \%$ & $66.5 \%$ & $83.2 \%$ & \\
\hline China & $11.0 \%$ & $49.7 \%$ & $95.3 \%$ & Floating \\
\hline India & $8.6 \%$ & $62.9 \%$ & $109.5 \%$ & Floating \\
\hline Indonesia & $5.3 \%$ & $29.6 \%$ & $44.1 \%$ & Floating \\
\hline Malaysia & $5.9 \%$ & $144.0 \%$ & $31.7 \%$ & Floating \\
\hline Philippines & $5.4 \%$ & $38.7 \%$ & $15.8 \%$ & Floating \\
\hline Korea, Rep. & $4.2 \%$ & $66.7 \%$ & $196.6 \%$ & Fixed \\
\hline Thailand & $5.8 \%$ & $74.1 \%$ & $89.2 \%$ & Floating \\
\hline
\end{tabular}




\begin{tabular}{|c|c|c|c|c|}
\hline \multicolumn{5}{|c|}{$2007-2014$} \\
\hline & GDP Growth & Market Size/GDP & Liquidity & Currency \\
\hline Americas & \multirow{5}{*}{$\begin{array}{l}4.1 \% \\
3.5 \% \\
4.1 \% \\
4.5 \% \\
2.0 \%\end{array}$} & \multirow{5}{*}{$\begin{array}{c}66.7 \% \\
61.9 \% \\
115.0 \% \\
59.5 \% \\
37.9 \%\end{array}$} & \multirow{5}{*}{$\begin{array}{l}26.9 \% \\
68.0 \% \\
19.8 \% \\
12.7 \% \\
28.1 \%\end{array}$} & \multirow{5}{*}{$\begin{array}{l}\text { Floating } \\
\text { Floating } \\
\text { Floating } \\
\text { Floating }\end{array}$} \\
\hline Brazil & & & & \\
\hline Chile & & & & \\
\hline Colombia & & & & \\
\hline $\begin{array}{c}\text { Mexico } \\
\text { Peru }\end{array}$ & & & & \\
\hline Europe and Africa & \multirow{9}{*}{$\begin{array}{l}1.7 \% \\
0.9 \% \\
4.3 \% \\
-3.6 \% \\
-0.4 \% \\
3.7 \% \\
2.8 \% \\
2.5 \% \\
3.5 \%\end{array}$} & \multirow{9}{*}{$\begin{array}{c}52.9 \% \\
22.5 \% \\
43.6 \% \\
28.1 \% \\
19.3 \% \\
33.5 \% \\
56.8 \% \\
184.1 \% \\
35.1 \% \\
\end{array}$} & \multirow{9}{*}{$\begin{array}{c}71.1 \% \\
43.7 \% \\
45.7 \% \\
52.2 \% \\
88.6 \% \\
48.7 \% \\
89.6 \% \\
57.1 \% \\
143.6 \%\end{array}$} & \multirow{9}{*}{$\begin{array}{c}\text { Floating } \\
\text { Floating } \\
\text { Currency Union } \\
\text { Currency Union } \\
\text { Floating } \\
\text { Floating } \\
\text { Floating } \\
\text { Floating } \\
\end{array}$} \\
\hline Czech Republic & & & & \\
\hline Egypt, Arab Rep. & & & & \\
\hline Greece & & & & \\
\hline Hungary & & & & \\
\hline Poland & & & & \\
\hline Russian Federation & & & & \\
\hline South Africa & & & & \\
\hline Turkey & & & & \\
\hline Asia & \multirow{8}{*}{$\begin{array}{l}5.7 \% \\
9.7 \% \\
7.3 \% \\
6.0 \% \\
4.7 \% \\
5.3 \% \\
3.5 \% \\
3.2 \%\end{array}$} & \multirow{8}{*}{$\begin{array}{l}83.5 \% \\
78.1 \% \\
81.1 \% \\
40.9 \% \\
141.1 \% \\
75.7 \% \\
88.2 \% \\
79.4 \%\end{array}$} & \multirow{8}{*}{$\begin{array}{c}90.0 \% \\
174.3 \% \\
76.7 \% \\
52.0 \% \\
33.8 \% \\
23.0 \% \\
184.5 \% \\
85.9 \%\end{array}$} & \multirow{8}{*}{$\begin{array}{c}\text { Floating } \\
\text { Floating } \\
\text { Floating } \\
\text { Floating } \\
\text { Floating } \\
\text { Fixed } \\
\text { Floating }\end{array}$} \\
\hline China & & & & \\
\hline India & & & & \\
\hline Indonesia & & & & \\
\hline Malaysia & & & & \\
\hline Philippines & & & & \\
\hline Korea, Rep. & & & & \\
\hline Thailand & & & & \\
\hline
\end{tabular}

Note: This table provides statistics on GDP growth, market size, liquidity and currency on the 21 emerging markets for the period of 2001-2002, 2003-2006 and 2007-2014.

Market Size/GDP represents the Average Market Capitalization as a ratio of the Real GDP during the period. Liquidity represents the Total Turnover in the stock market. It is calculated as Total Value of Shares traded as a ratio of market capitalization. Exchange Rate Regime has been acquired from Official IMF classifications of Exchange Rate Agreements. 


\section{Appendix II - Details of Methodology}

\subsection{Wavelet}

For each stock market, we collect daily return series for each stock index in the sample as well as for the market index. Daily stock index returns are calculated from stock price (P) as follows,

$$
r_{i t}=\ln \left(\frac{P_{i t}}{P_{i t-1}}\right) \text { for stock } i \text { at day } t
$$

While the daily return on the market index is calculated from the index value $(\mathrm{X})$ as follows:

$$
r_{m t}=\ln \left(\frac{X_{t}}{X_{t-1}}\right) \text { at day } t
$$

After calculating the return series for every stock index, we use wavelet analysis to be able to separate out each return series into its constituent multiresolution (multihorizon) components. To do that we apply Maximum Overlap discrete wavelet transformation (MODWT) on daily return series by sampling the return series at evenly-spaced points in time. We transform the return series from time domain into scale (interval) domain in order to understand the frequency at which the activity in the time series occurs. In our study, we sample the daily return series at different scale crystals (j) as follows: $\mathrm{d} 1$ (2-4 days), d2 (4-8 days) days, d3 (8-16 days), d4 (16-32 days), d5 (32-64 days), and s5 (>64 days).

We use non-decimated orthogonal Maximum Overlap Discrete Wavelet Transform (MODWT) with symmlet 8 as a wavelet function to obtain a multi-scale decomposition of the return series. The Maximum Overlap Discrete Wavelet Transform (MODWT) will be used with the advantage on the flexibility of the length of data (not requiring the integral power of two) as well as time invariant property. The wavelet family symmlet 8 is chosen to get the least asymmetry property which is more appropriate for financial series. The transformed return series $r(t)$ is represented as a linear combination of wavelet functions as follows:

$$
r(t) \approx \sum_{k} s_{j, k} \boldsymbol{\phi}_{j, k}(t)+\sum_{k} d_{j, k} \boldsymbol{\Psi}_{j, k}(t)+\sum_{k} d_{j-1, k} \boldsymbol{\Psi}_{j-1, k}(t)+\cdots \sum_{k} d_{1, k} \boldsymbol{\Psi}_{1, k}(t)
$$

where:

$\mathrm{j}$ is the number of scale crystals (intervals or frequencies)

$\mathrm{k}$ is the number of coefficients in the specified component

$\phi_{j, k(t)}$ and $\psi_{j, k(t)}$ are the father and mother orthogonal wavelet pair that are given respectively by

$$
\begin{aligned}
& \phi_{j, k}(t)=2^{-j / 2} \phi\left(\frac{t-2^{j} k}{2^{j}}\right) \text { for } j=1 \text { to } j \\
& \psi_{j, k}(t)=2^{-j / 2} \psi\left(\frac{t-2^{j} k}{2^{j}}\right) \text { for } j=j \text { to } 11
\end{aligned}
$$

Father wavelets represent the low-frequency (smooth) parts of the series, whereas mother wavelets represent the high-frequency (detailed) parts of the series. $s_{j, k}$ and $d_{j, k}$ are wavelet coefficients that are approximated by the following integrals:

$$
\begin{aligned}
s_{j, k} & \approx \int \phi_{j, k}(t) f(t) d t \\
d_{j, k} & \approx \int \psi_{j, k}(t) f(t) d t
\end{aligned}
$$

$s_{J, k}$ are called the 'smooth' coefficients that represent the underlying smooth behaviour of the series, while $d_{j, k}$ are called the 'detail' coefficients that represent the scale deviations from the smooth process. These coefficients are measures of the contribution of the corresponding wavelet function to the total series. After we decompose the return series into $j$ crystals, the 
crystals $d_{j}$ are recomposed into a time domain. The entire return series is replicated in multiresolution decomposition as follows:

$$
\widehat{r}=D_{1}+\ldots . D_{j}+S_{j}
$$

where $D_{j}$ is the recomposed series in the time domain from the crystal $d_{j}$ and $S_{J}$ is the recomposition of the residue. The reconstituted return series $r \hat{J}$ contain the separate components of the original series at each frequency $j$. $D_{j}$ represent the contribution of frequency $\mathrm{j}$ to the original series.

We use the summation of the decomposed scale $\mathrm{d} 1$ (2-4 days) and $\mathrm{d} 2$ (4-8 days) to represent the short term investor horizon, while the d5 (32-64 days), and s5 (>64 days) represent the long term investor horizon for our study.

\subsection{Exponential GARCH Volatility}

After obtaining our decomposed series through wavelet, our stock return is then run through EGARCH to obtain its volatility. Looking at the ordinary GARCH model, we can see that the conditional variance is allowed to be dependent on its past, however this standard model possess some limitations as it cannot include the leveraging effects, nor can it allow for a direct response between conditional variance and conditional mean. Hence, in this study we concentrate on the asymmetric GARCH model developed by Nelson (1991), the EGARCH model which is better suited for volatilities.

$$
\ln \sigma_{j, t}^{2}=\omega_{t}+\beta_{j} \ln \left(\sigma_{j, t-1)}^{2}+\gamma \frac{\varepsilon_{t-1}}{\sqrt{\sigma_{t-1}^{2}}}+\alpha\left[\frac{\left|\varepsilon_{t-1}\right|}{\sqrt{\sigma_{t-1}^{2}}}-\sqrt{\frac{2}{\pi}}\right]\right.
$$

Where $\sigma_{j, t}^{2}$ denotes the conditional variance since it is a one-period ahead estimate for the variance calculated on any past relevant information. $\omega_{t}$ symbolizes a conditional density function. The $\alpha$ consideration represents a symmetric effect of the model, i.e. the GARCH effect. $\beta$ calculates the perseverance in conditional volatility irrespective of market movements. Furthermore, the parameter $\gamma$ measures the leveraging effect.

The EGARCH model presides over other models with its ability to allow for a more stable optimization of routines, and no parameter constraints. Furthermore, Alexander (2009) concluded that EGARCH was beneficial in capturing asymmetric responses in the conditional variance at a more advanced level.

\subsection{Multivariate GARCH Correlation}

Moving on from the volatility aspect of our analysis, in order to determine the correlation as the integration measure for the decomposed series, we use Multivariate GARCH. MGARCH allows us to calculate the correlations, which can be used as a proxy for integration of the Turkish stock market with the regional benchmarks. Bauwens et. al. (2006) have reviewed MGARCH and its various applicability and have found it to be suitable for testing correlations and cointegration amongst countries. A brief technical note on the methodology is as follows.

Let $\mathrm{rt}$ be an $\mathrm{m} \times 1$ vector of asset returns at close day $\mathrm{t}$ assumed to have a conditional multivariate $\mathrm{t}$ distribution with means, $\mu \mathrm{t}-1$, and the non-singular variance-covariance matrix $\Sigma \mathrm{t}-1$, and vt-1 $>2$ degrees of freedom. Here we are not concerned with how mean returns are 
predicted and take $\mu \mathrm{t}-1$ as given. For specification of $\Sigma \mathrm{t}-1$ we follow Bollerslev (1990) and Engle (2002) consider the decomposition.

$$
\Sigma_{t-1}=D_{t-1} R_{t-1} D_{t-1}
$$

where,

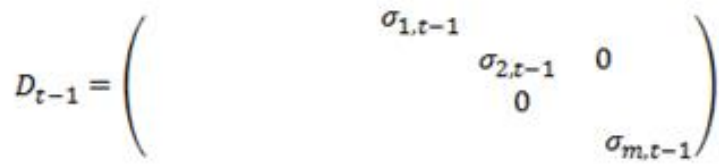

$$
\begin{aligned}
& R_{t-1}=\left(\begin{array}{ccccc}
1 & \rho_{12, t-1} & \rho_{13, t-1} & \cdots & \rho_{1 m, t-1} \\
\rho_{21, t-1} & 1 & \rho_{23, t-1} & \cdots & \rho_{2 m, t-1} \\
\rho_{31, t-1} & \rho_{32, t-1} & 1 & \cdots & \rho_{3 m, t-1} \\
\rho_{m 1, t-1} & \cdots & \rho_{m, m-1, t-1} & & \rho_{m-1, m, t-1}
\end{array}\right)
\end{aligned}
$$

Rt-1 $=(\rho \mathrm{ij}, \mathrm{t}-1)=(\rho \mathrm{ji}, \mathrm{t}-1)$ is the symmetric $\mathrm{mx}$ m correlation matrix, and Dt- 1 is the $\mathrm{m} \times \mathrm{m}$ diagonal matrix with $\sigma \mathrm{i}, \mathrm{t}-1 ; \mathrm{i}=1,2, \ldots, \mathrm{m}$ denoting the conditional volatility of the $\mathrm{i}$-th asset return. More specifically

$$
\sigma_{i, t-1}^{2}=V\left(r_{i t} \mid \Omega_{t-1}\right)
$$

and $\rho \mathrm{ij}, \mathrm{t}-1$ are conditional pair-wise return correlations defined by

$$
\rho_{i, j, t-1}=\frac{\operatorname{Cov}\left(r_{i t}, r_{j t} \mid \Omega_{t-1}\right)}{\sigma_{i, t-1} \sigma_{i, t-1}}
$$

where $\Omega \mathrm{t}-1$ is the information set available at close of day $\mathrm{t}-1$. Clearly, $\rho \mathrm{ij}, \mathrm{t}-1=1$; for $\mathrm{i}=\mathrm{j}$.

Bollerslev (1990) considers (9) with a constant correlation matrix Rt-1 = R. Engle (2002) allows for Rt-1 to be time-varying and proposes a class of multivariate GARCH models labeled as dynamic conditional correlation (DCC) models. An alternative approach would be to use the conditionally Heteroscedastic factor model where the vector of unobserved common factors are assumed to be conditionally heteroskedastic. Parsimony is achieved by assuming that the number of the common factors is much less than the number of assets under considerations.

The decomposition of $\Sigma$ t-1 in (9) allows separate specification of the conditional volatilities and conditional cross-asset returns correlations. For example, one can utilize the GARCH $(1,1)$ model for $\sigma^{2} \mathrm{i}, \mathrm{t}-1$, namely

$$
V\left(r_{i t} \mid \Omega_{t-1}\right)=\sigma_{i, t-1}^{2}=\overline{\sigma_{l}^{2}}\left(1-\lambda_{1 i}-\lambda_{2 i}\right)+\lambda_{1 i} \sigma_{i, t-2}^{2}+\lambda_{2 i} \sigma_{i, t-1}^{2}
$$

where $\sigma^{2} \mathrm{i}$ is the unconditional variance of the $\mathrm{i}$-th asset return. Under the restriction $\lambda 1 \mathrm{i}+\lambda 2 \mathrm{i}=1$, the unconditional variance does not exist and we have the integrated GARCH (IGARCH) model used extensively in the professional financial community, which is mathematically equivalent to the exponential smoother applied to the $\mathrm{r}^{2} \mathrm{it}^{\mathrm{s}} \mathrm{s}^{2}$

$$
\sigma_{i, t-1}^{2}\left(\lambda_{i}\right)=\left(1-\lambda_{i}\right) \sum_{s=1}^{\infty} \lambda_{i}^{s-1} r_{i, t-s}^{2} \quad 0<\lambda_{i}^{m}<1
$$

For cross-asset correlations Engle proposes the use of the following exponential smoother applied to the standardized returns 


$$
\hat{\rho}_{i j, t-1}(\emptyset)=\frac{\sum_{s=1}^{\infty} \emptyset_{i}^{s-1} z_{i, t-s} z_{j, t-s}}{\sqrt{\sum_{s=1}^{\infty} \emptyset^{s-1} z_{i, t-s}} \sqrt{\sum_{s=1}^{\infty} \emptyset^{s-1} z_{j, t-s}}}
$$

where the standardized returns are defined by

$$
z_{i t}=\frac{r_{i t}}{\sigma_{i, t-1}\left(\lambda_{i}\right)}
$$

For estimation of the unknown parameters, $\lambda 1, \lambda 2, \lambda 3, \ldots \lambda \mathrm{m}$, and $\phi$, Engle (2002) proposes a two-step procedure whereby in the first step individual $\operatorname{GARCH}(1,1)$ models are fitted to the $\mathrm{m}$ asset returns separately, and then the coefficient of the conditional correlations, $\phi$, is estimated by the Maximum Likelihood method with an assumption that asset returns are conditionally Gaussian. This procedure has two main drawbacks. First, the Gaussianity assumption does not hold for daily returns and its use can under-estimate the portfolio risk. Second, the two-stage approach is likely to have even coefficient under Gaussianity. 


\section{Appendix III - Efficiency Measure across different periods.}

2001-2002

\begin{tabular}{|c|c|c|c|c|}
\hline Short term & & & Long term & \\
\hline S. Africa - Eur. \& Afr. & 0.064 & 1 & China - Asia & 0.0 \\
\hline Czech - Eur. \& Afr. & 0.065 & 2 & South Korea - Asia & 0.0 \\
\hline Russia - Eur. \& Afr. & 0.069 & 3 & Brazil - Amer. & 0.0 \\
\hline Mexico - Amer. & 0.073 & 4 & Czech - Eur. \& Afr. & 0.0 \\
\hline South Korea - Asia & 0.082 & 5 & Turkey - Eur. \& Afr. & 0.1 \\
\hline Poland - Eur. \& Afr. & 0.087 & 6 & Thailand - Asia & 0.1 \\
\hline China - Asia & 0.113 & 7 & Russia - Eur. \& Afr. & 0.1 \\
\hline Turkey - Eur. \& Afr. & 0.121 & 8 & $\begin{array}{l}\text { Hungary - Eur. \& } \\
\text { Afr. }\end{array}$ & 0.1 \\
\hline Thailand - Asia & 0.132 & 9 & Mexico - Amer. & 0.1 \\
\hline Brazil - Amer. & 0.146 & 10 & Chile - Amer. & 0.1 \\
\hline Taiwan - Asia & 0.149 & 11 & $\begin{array}{l}\text { S. Africa - Eur. \& } \\
\text { Afr. }\end{array}$ & \\
\hline India - Asia & 0.153 & 12 & Taiwan - Asia & 0.1 \\
\hline Greece - Eur. \& Afr. & 0.158 & 13 & Poland - Eur. \& Afr. & 0.1 \\
\hline Peru - Amer. & 0.16 & 14 & Peru - Amer. & 0.1 \\
\hline Malaysia - Asia & 0.175 & 15 & Greece - Eur. \& Afr. & 0.1 \\
\hline Hungary - Eur. \& Afr. & 0.185 & 16 & Malaysia - Asia & 0.1 \\
\hline Colombia - Amer. & 0.197 & 17 & India - Asia & $0.1^{\top}$ \\
\hline Egypt - Eur. \& Afr. & 0.204 & 18 & Colombia - Amer. & 0.1 \\
\hline Philippines - Asia & 0.214 & 19 & Egypt - Eur. \& Afr. & 0.1 \\
\hline Chile - Amer. & 0.219 & 20 & Philippines - Asia & 0.2 \\
\hline Indonesia - Asia & 0.317 & 21 & Indonesia - Asia & \\
\hline
\end{tabular}

2001-2002

Short term Long term

Americas

\begin{tabular}{|c|c|c|c|c|c|}
\hline 1 & Mexico - Amer. & 0.073 & 1 & Brazil - Amer. & 0.068 \\
\hline & Brazil - Amer. & 0.146 & 2 & Mexico - Amer. & 0.124 \\
\hline & Peru - Amer. & 0.16 & 3 & Chile - Amer. & 0.128 \\
\hline & Colombia - Amer. & 0.197 & 4 & Peru - Amer. & 0.138 \\
\hline & Chile - Amer. & 0.219 & 5 & Colombia - Amer. & 0.174 \\
\hline \multicolumn{6}{|c|}{ Europe and Africa } \\
\hline & $\begin{array}{l}\text { S. Africa - Eur. \& } \\
\text { Afr. }\end{array}$ & 0.064 & 1 & Czech - Eur. \& Afr. & 0.083 \\
\hline & Czech - Eur. \& Af & 0.065 & 2 & Turkey - Eur. \& Afr. & 0.106 \\
\hline & $\begin{array}{l}\text { Russia - Eur. \& } \\
\text { Afr. }\end{array}$ & 0.069 & 3 & Russia - Eur. \& Afr. & 0.118 \\
\hline & $\begin{array}{l}\text { Poland - Eur. \& } \\
\text { Afr. }\end{array}$ & 0.087 & 4 & $\begin{array}{l}\text { Hungary - Eur. \& } \\
\text { Afr. }\end{array}$ & 0.122 \\
\hline & $\begin{array}{l}\text { Turkey - Eur. \& } \\
\text { Afr. }\end{array}$ & 0.121 & 5 & $\begin{array}{l}\text { S. Africa - Eur. \& } \\
\text { Afr. }\end{array}$ & 0.128 \\
\hline & $\begin{array}{l}\text { Greece - Eur. \& } \\
\text { Afr. }\end{array}$ & 0.158 & 6 & Poland - Eur. \& Afr. & 0.136 \\
\hline & $\begin{array}{l}\text { Hungary - Eur. \& } \\
\text { Afr. }\end{array}$ & 0.185 & 7 & Greece - Eur. \& Afr. & 0.156 \\
\hline & Egypt - Eur. \& Afr. & 0.204 & 8 & Egypt - Eur. \& Afr. & 0.199 \\
\hline & \multicolumn{5}{|c|}{ Asia } \\
\hline & South Korea - Asia & 0.082 & 1 & China - Asia & 0.026 \\
\hline & China - Asia & 0.113 & 2 & South Korea - Asia & 0.062 \\
\hline & Thailand - Asia & 0.132 & 3 & Thailand - Asia & 0.106 \\
\hline & Taiwan - Asia & 0.149 & 4 & Taiwan - Asia & 0.135 \\
\hline & India - Asia & 0.153 & 5 & Malaysia - Asia & 0.169 \\
\hline & Malaysia - Asia & 0.175 & 6 & India - Asia & 0.174 \\
\hline & Philippines - Asia & 0.214 & 7 & Philippines - Asia & 0.211 \\
\hline & Indonesia - Asia & 0.317 & 8 & Indonesia - Asia & 0.237 \\
\hline
\end{tabular}

The efficiency measure is calculated using $\mathrm{mf}$-dfa for the time period under consideration. The short term horizon factors in the decomposed stock market return for less than 8 days, while long term horizon captures the decomposed stock returns for more than 32 days

2003-2006

\begin{tabular}{|c|c|c|c|c|}
\hline \multicolumn{2}{|l|}{ Short term } & & \multicolumn{2}{|l|}{ Long term } \\
\hline Brazil - Amer. & 0.016 & 1 & China - Asia & 0.02 \\
\hline India - Asia & 0.045 & 2 & Taiwan - Asia & 0.029 \\
\hline Turkey - Eur. \& Afr. & 0.048 & 3 & Thailand - Asia & 0.059 \\
\hline Greece - Eur. \& Afr. & 0.056 & 4 & Peru - Amer. & 0.064 \\
\hline Mexico - Amer. & 0.062 & 5 & Chile - Amer. & 0.067 \\
\hline Poland - Eur. \& Afr. & 0.062 & 6 & Malaysia - Asia & 0.09 \\
\hline South Korea - Asia & 0.07 & 7 & $\begin{array}{l}\text { S. Africa - Eur. \& } \\
\text { Afr. }\end{array}$ & 0.093 \\
\hline Hungary - Eur. \& Afr. & 0.081 & 8 & Turkey - Eur. \& Afr. & 0.098 \\
\hline Czech - Eur. \& Afr. & 0.088 & 9 & Russia - Eur. \& Afr. & 0.102 \\
\hline Egypt - Eur. \& Afr. & 0.093 & 10 & Colombia - Amer. & 0.108 \\
\hline
\end{tabular}

2003-2006

\begin{tabular}{|c|c|c|c|c|}
\hline \multicolumn{2}{|l|}{ Short term } & & \multicolumn{2}{|l|}{ Long term } \\
\hline \multicolumn{5}{|c|}{ Americas } \\
\hline Brazil - Amer. & 0.016 & 1 & Peru - Amer. & 0.064 \\
\hline Mexico - Amer. & 0.062 & 2 & Chile - Amer. & 0.067 \\
\hline Peru - Amer. & 0.109 & 3 & Colombia - Amer. & 0.108 \\
\hline Chile - Amer. & 0.126 & 4 & Brazil - Amer. & 0.13 \\
\hline Colombia - Amer. & 0.219 & 5 & Mexico - Amer. & 0.172 \\
\hline \multicolumn{5}{|c|}{ Europe and Africa } \\
\hline $\begin{array}{l}\text { Turkey - Eur. \& } \\
\text { Afr. }\end{array}$ & 0.048 & 1 & $\begin{array}{l}\text { S. Africa - Eur. \& } \\
\text { Afr. }\end{array}$ & 0.093 \\
\hline $\begin{array}{l}\text { Greece - Eur. \& } \\
\text { Afr. }\end{array}$ & 0.056 & 2 & Turkey - Eur. \& Afr. & 0.098 \\
\hline $\begin{array}{l}\text { Poland - Eur. \& } \\
\text { Afr. }\end{array}$ & 0.062 & 3 & Russia - Eur. \& Afr. & 0.102 \\
\hline
\end{tabular}




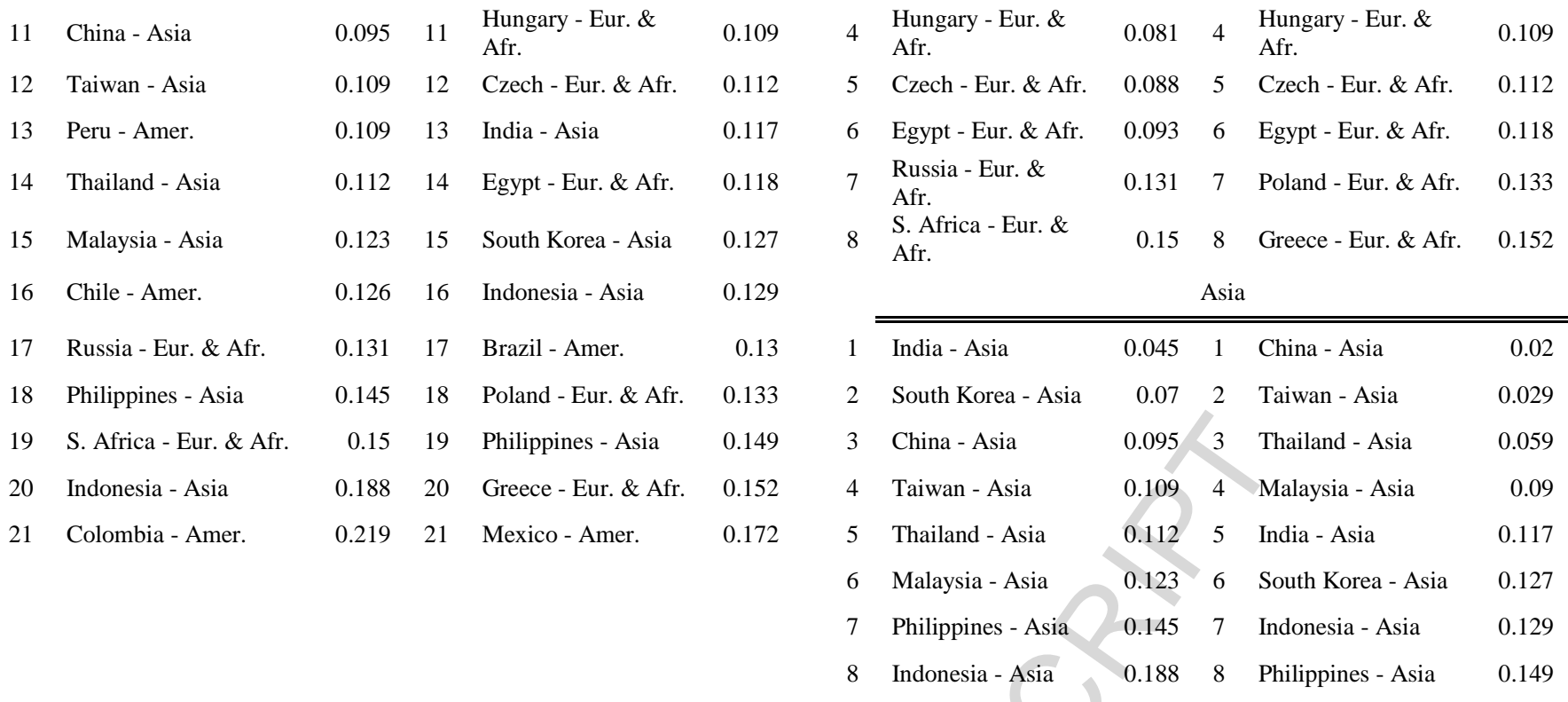

The efficiency measure is calculated using mf-dfa for the time period under consideration. The short term horizon factors in the decomposed stock market return for less than 8 days, while long term horizon captures the decomposed stock returns for more than 32 days

2006-2014

\begin{tabular}{|c|c|c|c|c|}
\hline \multicolumn{2}{|l|}{ Short term } & \multicolumn{3}{|c|}{ Long term } \\
\hline Peru - Amer. & 0.077 & 1 & Mexico - Amer. & 0.018 \\
\hline S. Africa - Eur. \& Afr. & 0.099 & 2 & Russia - Eur. \& Afr. & 0.032 \\
\hline Hungary - Eur. \& Afr. & 0.113 & 3 & China - Asia & 0.035 \\
\hline Turkey - Eur. \& Afr. & 0.115 & 4 & South Korea - Asia & 0.036 \\
\hline Greece - Eur. \& Afr. & 0.127 & 5 & Czech - E & 0.038 \\
\hline Thailand - Asia & 0.135 & 6 & $\begin{array}{l}\text { Hungar } \\
\text { Afr. }\end{array}$ & 0.043 \\
\hline India - Asia & 0.147 & 7 & Poland - & 0.045 \\
\hline Colombia - Amer. & 0.147 & 8 & Brazil - Amer. & 0.051 \\
\hline China - Asia & 0.151 & 9 & Thailand - Asia & 0.052 \\
\hline Indonesia - Asia & 0.153 & 10 & Philippines - Asia & 0.064 \\
\hline Brazil - Amer. & 0.159 & 1 & Taiwan - Asia & 0.066 \\
\hline Poland - Eur. \& Afr. & 0.162 & 12 & Chile - Amer. & 0.069 \\
\hline Taiwan - Asia & 0.174 & 13 & Indonesia - Asia & 0.069 \\
\hline Philippines - Asia & 0.174 & 14 & Colombia - Amer. & 0.082 \\
\hline Mexico - Amer. & 0.177 & 15 & India - Asia & 0.087 \\
\hline Malaysia - Asia & 0.186 & 16 & $\begin{array}{l}\text { S. Africa - Eur. \& } \\
\text { Afr. }\end{array}$ & 0.092 \\
\hline Chile - Amer. & 0.188 & 17 & Peru - Amer. & 0.096 \\
\hline Czech - Eur. \& Afr. & 0.207 & 18 & Malaysia - Asia & 0.101 \\
\hline Russia - Eur. \& Afr. & 0.234 & 19 & Turkey - Eur. \& Afr. & 0.12 \\
\hline South Korea - Asia & 0.239 & 20 & Egypt - Eur. \& Afr. & 0.144 \\
\hline & & 21 & Greece - Eur. \& Afr. & 0.247 \\
\hline
\end{tabular}

2006-2014

Short term Long term

Americas

\begin{tabular}{llllll}
\hline \hline 1 & Peru - Amer. & 0.077 & 1 & Mexico - Amer. & 0.018 \\
2 & Colombia - Amer. & 0.147 & 2 & Brazil - Amer. & 0.051 \\
3 & Brazil - Amer. & 0.159 & 3 & Chile - Amer. & 0.069 \\
4 & Mexico - Amer. & 0.177 & 4 & Colombia - Amer. & 0.082 \\
5 & Chile - Amer. & 0.188 & 5 & Peru - Amer. & 0.096
\end{tabular}

Europe and Africa

\begin{tabular}{|c|c|c|c|c|}
\hline $\begin{array}{l}\text { S. Africa - Eur. \& } \\
\text { Afr. }\end{array}$ & 0.099 & 1 & Russia - Eur. \& Afr. & 0.032 \\
\hline $\begin{array}{l}\text { Hungary - Eur. \& } \\
\text { Afr. }\end{array}$ & 0.113 & 2 & Czech - Eur. \& Afr. & 0.038 \\
\hline $\begin{array}{l}\text { Turkey - Eur. \& } \\
\text { Afr. }\end{array}$ & 0.115 & 3 & $\begin{array}{l}\text { Hungary - Eur. \& } \\
\text { Afr. }\end{array}$ & 0.043 \\
\hline $\begin{array}{l}\text { Greece - Eur. \& } \\
\text { Afr. }\end{array}$ & 0.127 & 4 & Poland - Eur. \& Afr. & 0.045 \\
\hline $\begin{array}{l}\text { Poland - Eur. \& } \\
\text { Afr. }\end{array}$ & 0.162 & 5 & $\begin{array}{l}\text { S. Africa - Eur. \& } \\
\text { Afr. }\end{array}$ & 0.092 \\
\hline Czech - Eur. \& Afr. & 0.207 & 6 & Turkey - Eur. \& Afr. & 0.12 \\
\hline $\begin{array}{l}\text { Russia - Eur. \& } \\
\text { Afr. }\end{array}$ & 0.234 & 7 & Egypt - Eur. \& Afr. & 0.144 \\
\hline Egypt - Eur. \& Afr. & & 8 & Greece - Eur. \& Afr. & 0.247 \\
\hline
\end{tabular}

\begin{tabular}{llllll}
\hline & Thailand - Asia & 0.135 & 1 & China - Asia & 0.035 \\
2 & India - Asia & 0.147 & 2 & South Korea - Asia & 0.036 \\
3 & China - Asia & 0.151 & 3 & Thailand - Asia & 0.052 \\
4 & Indonesia - Asia & 0.153 & 4 & Philippines - Asia & 0.064 \\
5 & Taiwan - Asia & 0.174 & 5 & Taiwan - Asia & 0.066 \\
6 & Philippines - Asia & 0.174 & 6 & Indonesia - Asia & 0.069 \\
7 & Malaysia - Asia & 0.186 & 7 & India - Asia & 0.087
\end{tabular}


The efficiency measure is calculated using $\mathrm{mf}$-dfa for the time period under consideration. The short term horizon factors in the decomposed stock market return for less than 8 days, while long term horizon captures the decomposed stock returns for more than 32 days. 


\section{Highlights}

- Stock market data for emerging markets are multifractal in nature.

- The markets show improving efficiency over the decade particularly in the long term

- Efficiency was higher post liberalization of markets

- Emerging markets are more integrated with World now than a decade ago. 